\title{
Antibacterial Properties of hLf1-11 Peptide onto Titanium Surfaces: A Comparison Study Between Silanization and Surface Initiated Polymerization
}

Maria Godoy-Gallardo ${ }^{\dagger \neq}$, Carlos Mas-Moruno ${ }^{\dagger \neq \$}$, Kai Yü, José M. Manero ${ }^{\dagger \neq \$}$, Francisco J. Gil †\$, Jayachandran N. Kizhakkedathu ${ }^{\#, \delta}$, Daniel Rodriguez $* * \$$.

${ }^{\dagger}$ Biomaterials, Biomechanics and Tissue Engineering Group, Department of Materials Science and Metallurgy, Technical University of Catalonia (UPC), ETSEIB, Av. Diagonal 647, 08028Barcelona, Spain.

$¥$ Biomedical Research Networking Centre in Bioengineering, Biomaterials and Nanomedicine (CIBER-BBN), Campus Río Ebro, Edificio I+D Bloque 5, $1^{\mathrm{a}}$ planta, C/ Poeta Mariano Esquillor s/n, 50018-Zaragoza, Spain.

${ }^{\S}$ Centre for Research in NanoEngineering (CRNE) - UPC, C/ Pascual i Vila 15, 08028Barcelona, Spain

${ }^{\#}$ Centre for Blood Research and Department of Pathology and Laboratory Medicine, University of British Columbia, Life Sciences Centre, 2350 Health Sciences Mall, Vancouver, BC, Canada, V6T 1 Z3

${ }^{\delta}$ Department of Chemistry, University of British Columbia, 2036 Main Mall, Vancouver, BC, Canada, V6T 1Z1

KEYWORDS: Titanium, lactoferrin peptide, ATRP, silanization, antibacterial coating 
ABSTRACT: Dental implant failure can be associated to infections which develop into periimplantitis. In order to reduce biofilm formation, several strategies focusing on the use of antimicrobial peptides (AMP) have been studied. To covalently immobilize these molecules onto metallic substrates several techniques have been developed, including silanization and polymer brush prepared by surface-initiated atom transfer radical polymerization (ATRP), with varied peptide binding yield and antibacterial performance. The aim of the present study was to compare the efficiency of these methods to immobilize the lactoferrin-derived hLf1-11 antibacterial peptide onto titanium, and evaluate their antibacterial activity in vitro.

Smooth titanium samples were coated with hLf1-11 peptide under three different conditions: silanization with APTES, and polymer brush based coatings with two different silanes. Peptide presence was determined by X-ray photoelectron spectroscopy and the mechanical stability of the coatings was studied under ultrasonication. The LDH assays confirmed that HFFs viability and proliferation were no affected by the treatments. The in vitro antibacterial properties of the modified surfaces were tested with two oral strains (Streptococcus sanguinis and Lactobacillus salivarius) showing an outstanding reduction. A higher decrease in bacterial attachment was noticed when samples were modified by ATRP methods compared to silanization. This effect is likely due to the capacity to immobilize more peptide on the surfaces using polymer brushes and the non-fouling nature of polymer PDMA segment. 


\section{INTRODUCTION}

The clinical success of a dental implant depends on the capacity of the implant material to establish an optimal and long-lasting osseointegration with the bone tissue. However, the presence of bacteria surrounding the implant critically affects this biological process and seriously compromises the long-term stability of the implant. In this regard, peri-implantitis, an inflammatory disease caused by bacteria and biofilm formation on the implant surface, has been described as a major cause of implant failure in the case of dental implants ${ }^{1}$.

Oral biofilm formation is a complex process which involves more than 500 different bacterial species $^{2,3}$. Its development is dependent on the adhesion of bacteria to salivary components adsorbed onto the tooth surface. Primary colonizers (e.g. Streptococcus gordonii, Streptococcus mitis, Streptococcus oralis and Streptococcus sanguinis) are abundant in oral biofilm ${ }^{4,5}$ and have crucial roles in the formation of dental plaque. Once these early colonizers adhere to the pellicle surface, a multi-layered bacterial biofilm is formed by bacterial growth and co-adherence of further bacteria. Moreover, some of these strains, e.g. Lactobacillus salivarius, contribute to control the $\mathrm{pH}$ of the plaque $\mathrm{e}^{6,7}$.

In order to reduce implant failure associated to bacterial infections, the immobilization of antimicrobial peptides (AMPs) onto implant surfaces has been studied ${ }^{8,9}$. In general, AMPs are cationic, often amphipathic, which primarily kill bacteria by interacting and disrupting their cell membrane ${ }^{10-13}$. In a previous study, we introduced the 1-11 antimicrobial sequence of the human lactoferrin protein (hLf), the hLf1-11 peptide, as a potent AMP with capacity to reduce bacterial adhesion on titanium implants ${ }^{8}$. Lactoferrin and Lf-derived peptides have been shown to inhibit viral $^{14}$, fungal ${ }^{15}$, parasitic and bacterial infections ${ }^{16-18}$. The antibacterial activity of lactoferrin has been widely documented both in vitro and in vivo for Gram-positive and Gram-negative bacteria ${ }^{19}$. The mechanism against Gram-negative bacteria cons ists in the interaction with lipopolysaccharide (LPS). The positively charged region at the N-terminus of lactoferrin prevents the interaction between LPS and the cations $\left(\mathrm{Ca}^{2+}\right.$ and $\left.\mathrm{Mg}^{2+}\right)$, causing a release of LPS from the cell wall, an increase in the membrane's permeability and ensuing damage to the bacteria. The mechanism of action against Gram-positive bacteria is also based on the binding of the positively charged peptides to the anionic molecules on the bacterial surface, resulting in a reduction of the negative charge of the cell wall ${ }^{19-22}$. Indeed, the immobilization of the hLf1-11 peptide onto titanium surfaces by silanization resulted in an outstanding decrease in the adhesion of Streptococcus sanguinis and Lactobacillus salivarius, and inhibition of early stages of biofilm formation, in comparison with control titanium ${ }^{8}$.

Silanization has been successfully used to functionalize metallic biomaterials with bioactive $\mathrm{e}^{8,23-}$ ${ }^{26}$. This method of surface modification allows the covalent attachment of peptides and proteins through the use of organofunctional alkoxysilane molecules that react with hydroxyl groups present at the surface of the material. In this regard, 3-aminopropyltriethoxysilane (APTES) has been widely used to covalently attach cell adhesive peptides (i.e. RGD peptides) ${ }^{25-27}$, and more 
recently $\mathrm{AMPs}^{8,28,29}$, onto titanium surfaces. The binding of these biomolecules onto aminosilanized samples often requires the reaction with crosslinking agents (i.e. glutaraldehyde, maleimide-based molecules) to ensure the appropriate chemical reactivity.

However, it should be mentioned that the yields of both the addition of the crosslinker and the binding of the peptide are rather low ${ }^{25,26}$. Thus, the efficiency of peptide immobilization onto silanized samples may be improved.

Another strategy to functionalize solid surfaces and improve the efficiency of peptide attachment is by grafting of polymer brushes by surface initiated polymerization ${ }^{30}$. Polymer brushes consist of an assembly of polymer chains connected to the solid substrate by one terminal of the chain $^{31,32}$. Generally, there are two ways to anchor polymer chains to the surfaces: by physical adsorption (physisorption) or covalent binding. Covalent attachment improves some disadvantages of physisorption, such as the low thermal and solvent stability obtained with the latter $^{33-35}$. The fabrication of polymer brushes can be achieved by the "grafting from" approach, which comprises the addition of a polymerization initiator onto the solid surface followed by the synthesis of polymer chains in situ on the solid substrate ${ }^{31,34}$. In recent years, atom transfer radical polymerization (ATRP) processes have been used extensively for the preparation of bioactive polymer brushes for a number of biomedical applications including antifouling, antibacterial, stimuli-responsive bioactive and patterned surfaces, and functional biomaterials, including polymeric delivery systems and polymer biomolecule bioconjugates ${ }^{32,36,37}$. In comparison with other surface modification methods (e.g. silanization), polymer brushes can increase the spatial density of a diverse number of functional groups on a surface, thereby allowing the conjugation of a higher number of biomolecules (Figure 1). Moreover, these systems have been shown to be mechanically and chemically stable 38,39 .

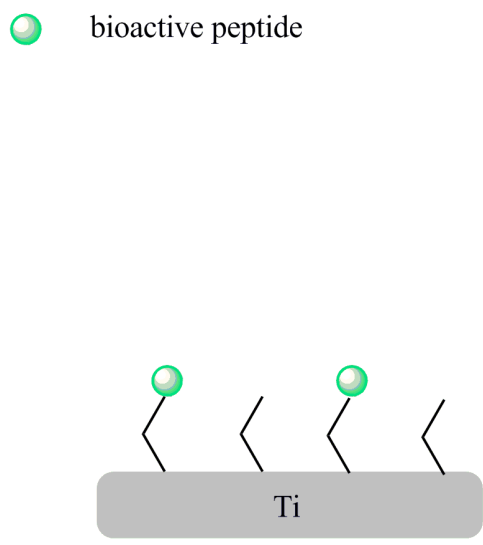

Silanization

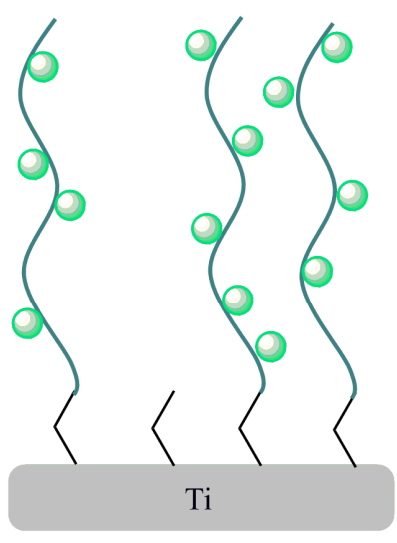

atom-transfer radical polymerization (ATRP)

Figure 1. Schematic representation of surface modification by silanization and surface initiated polymerization. 
Based on these premises, the aim of the present study was to compare the efficiency of silanization and ATRP methods to immobilize the hLf1-11 peptide on titanium to develop surfaces with antimicrobial properties for dental applications. To the best of our knowledge, such comparative study has not been reported in the literature. To this end, the surface physicochemical properties and the presence of peptide on the functionalized materials were studied by contact angle and surfaces energy calculations, white light interferometry, ellipsometry, and X-ray photoelectron spectroscopy (XPS). The stability of the coatings was studied by ultrasonication in water. The in vitro biological performance of the biomaterials was investigated by means of bacterial adhesion, growth and biofilm formation of Streptococcus sanguinis and Lactobacillus salivarius. Moreover, the toxicity of these samples to human cells was analyzed with human foreskin fibroblasts adhesion.

\section{MATERIAL AND METHODS}

\subsection{Chemicals and instrumentation}

Commercially pure (c.p.) grade 2 titanium bars were acquired from Zapp (Unna, Germany) with chemical and mechanical properties according to the standard ISO 5832-2. APTES, 3(maleimide)propionic acid N-hydroxysuccinimide ester, iodoacetic acid N-hydroxysuccinimide, N,N-dimethylacrylamide (DMA), N-(3-aminopropyl)methacrylamide hydrochloride (APMA), and the Karstedt catalyst were obtained from Sigma-Aldrich (St Louis, MO, USA). All other chemicals and solvents were purchased from Sigma-Aldrich, Alfa Aesar (Karlsruhe, Germany), SDS (Peypin, France), and Panreac (Castellar del Vallès, Spain) at the highest purity available and used without further purification.

The hLf1-11 peptide, containing three 6-aminohexanoic acid (Ahx) residues as spacer and a 3mercaptopropionic acid (MPA) as anchoring group [MPA-Ahx-Ahx-Ahx-GRRRRSVQWCA$\mathrm{NH}_{2}$ ], was synthesized in solid-phase, purified and characterized as previously reported ${ }^{8}$. This peptide was used to coat the aminosilanized samples. Alternatively, for samples grafted with polymer brushes, the same bactericidal peptide sequence without the spacer system was purchased from GenScript Corp (Piscataway, NJ, USA). Both peptides had a purity of $98 \%$ by HPL.

Human foreskin fibroblasts (HFFs) were purchased from Merck Millipore Corporation (Bedford, MA, USA), mammalian protein extraction reagent (M-PER $\left.{ }^{\circledR}\right)$ from Pierce (Rockford, IL, USA) and Dulbecco's Modified Eagle Medium (DMEM) from Invitrogen (Carlsbad, CA, USA). Cytotoxicity Detection Kit LDH was acquired from Roche Applied Science (Mannheim, Switzerland), LIVE/DEAD BackLight bacterial viability kit from Invitrogen, and BacTiter-Glo Reagent from Promega (Madison, WI, USA). Streptococcus sanguinis was obtained from Colección Española de Cultivos Tipo (CECT) (CECT 480) and Lactobacillus salivarius from the Culture Collection University of Göteborg (CCUG) (CCUG 17826). Bacterial growth media were bought from Scharlab SL (Sentmenat, Spain). All other reagents used for the biological assays were purchased from Invitrogen. 

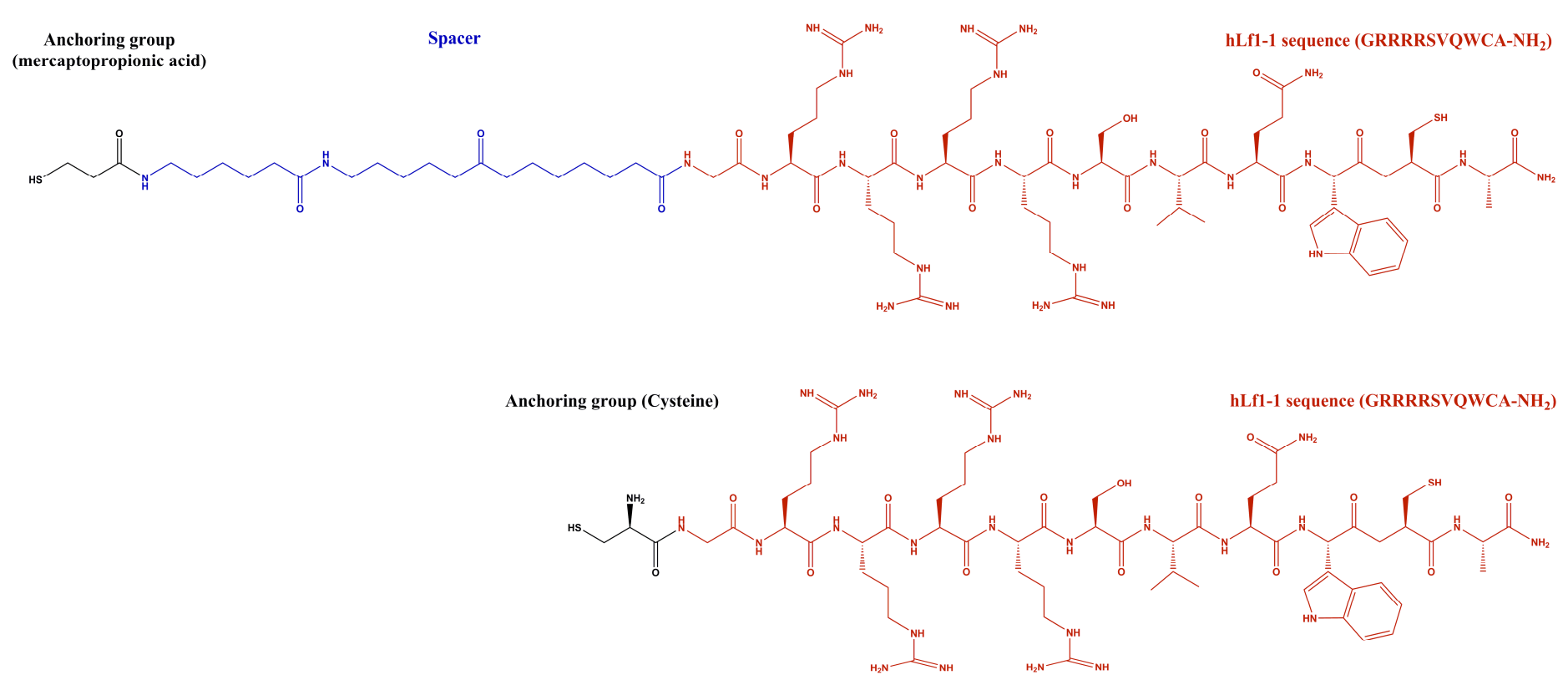

Figure 2. Chemical structure of Lf1-11 peptide with and without spacer. The distinct functional moieties are differentiated with colors.

\subsection{Sample preparation}

Cylindrical samples of c.p. grade 2 titanium (10 mmm diameter and $2 \mathrm{~mm}$ thickness) were polished until an average roughness $\left(\mathrm{R}_{\mathrm{a}}\right)$ under $40 \mathrm{~nm}$ was obtained. Prior to treatment, the samples were ultrasonically cleaned with isopropanol, ethanol, water and acetone for 15 minutes each.

For ellipsometry measurements, silica wafers coated with titanium were fabricated. First the wafers were cut with a dicing getting a size $1.4 \times 1.4 \mathrm{~cm}^{2}$. The titanium films were deposited using an electron beam gun Univex 350 (Oerlikon Leybold Vaccum, Germany) with a chamber pressure of $10^{-7}$ bar. The thickness of the titanium layer obtained was of $50 \mathrm{~nm}$.

\subsection{Functionalization of titanium samples via silanization (Strategy 1)}

Titanium samples were activated by oxygen plasma treatment (RF generator, Diener, Germany) for $10 \mathrm{~min}$ at a power of $100 \mathrm{~W}$. Titanium disks were immersed in a solution of APTES $(0.5 \%$, $\mathrm{v} / \mathrm{v}$ ) in anhydrous toluene for $1 \mathrm{~h}$ at $70{ }^{\circ} \mathrm{C}$ with stirring and under nitrogen atmosphere. After reaction completion, titanium samples were ultrasonically cleaned with toluene and washed with acetone, isopropanol, ethanol, distilled water and acetone and dried with nitrogen. Aminosilanized samples were further modified by reaction with $1 \mathrm{mg} / \mathrm{ml}$ of the bifunctional crosslinker iodoacetic acid N-hydroxysuccinimide ester in N,N-dimethylformamide (DMF) for 1 $\mathrm{h}$ at room temperature. After this time, the samples were washed with DMF, acetone, ethanol, distilled water and acetone, and dried with nitrogen. Finally, the hLf1-11 peptide was dissolved in phosphate buffered saline (PBS) at $1 \mathrm{mg} / \mathrm{ml}$ and $100 \mu \mathrm{L}$ of these solutions were deposited 
onto the titanium samples overnight at room temperature. After peptide incubation, samples were gently washed with PBS and dried with nitrogen.

\subsection{Functionalization of titanium samples via copolymer brushes (Strategies 2 and 3)}

This process was performed according to previous protocols reported by Gao et $a l^{38,40}$. In summary, the synthesis of copolymer brushes onto titanium surfaces involves the following steps: first, an atom transfer radical polymerization (ATRP) initiator is immobilized on the surfaces. Then, the polymerization is carried out on the surface with copolymerization of DMA and APMA ("grafting from" method). This reaction is followed by the functionalization of the copolymer brush with a crosslinker, and finally the hLf1-11 peptide is covalently attached (Figure 2). The difference between strategies 2 and 3 resides in the use of two different silanes: APTES and 11-(2-bromo-2-methyl)propionyloxyundecenyltrichlorosilane (BPTCS).

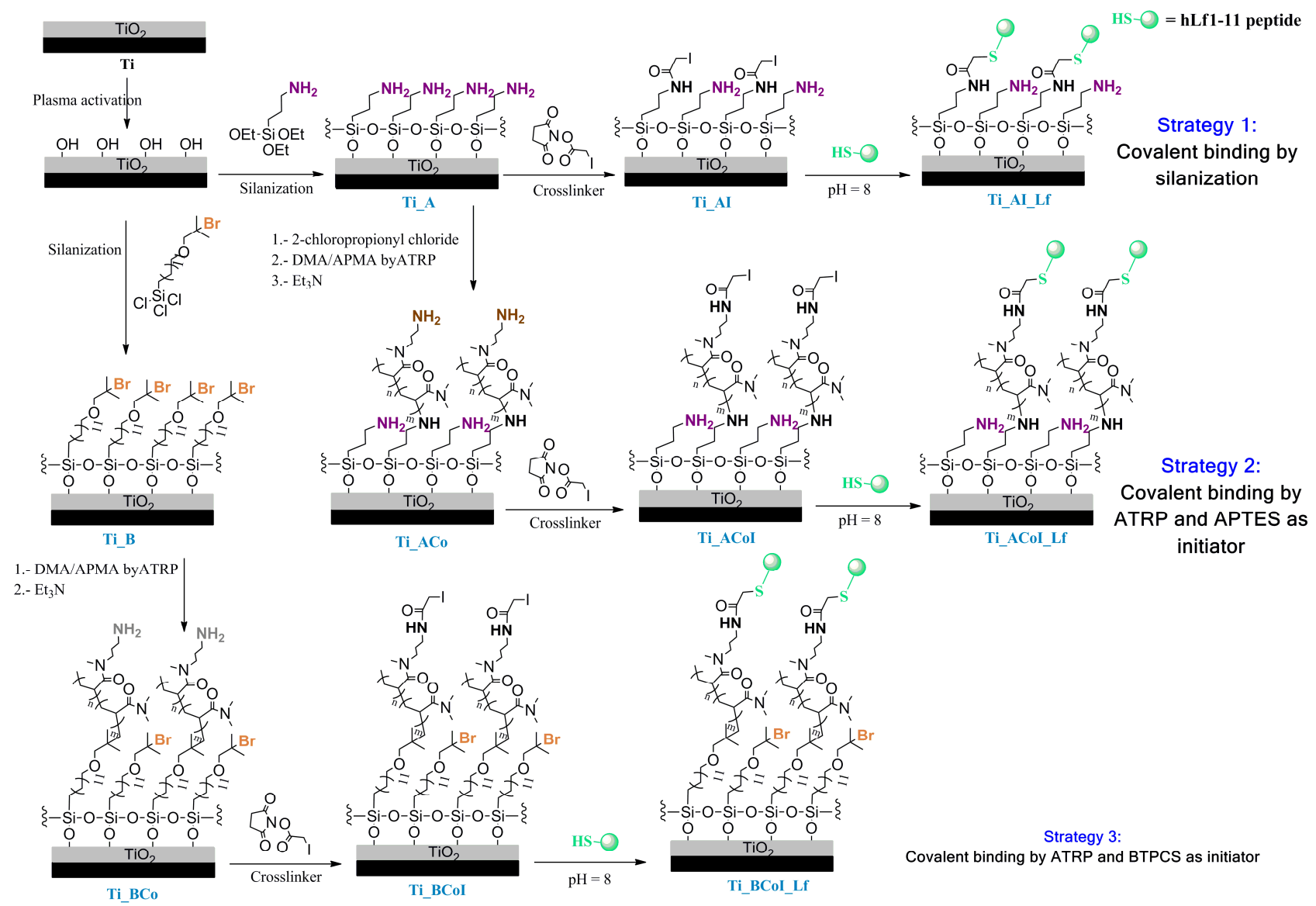

Figure 3. Synthetic route for functionalization strategies 1, 2 and 3.

\subsubsection{Immobilization of the ATRP initiators}

The silanization of titanium surfaces with APTES was performed as previously explained (see Section 2.3). Prior to ATRP, aminosilanized samples were activated by reaction with 2- 
chloropropionyl chloride. To this end, titanium samples were immersed in $30 \mathrm{ml}$ of dichloromethane (DCM), and 2-chloropropionyl chloride $(2.5 \mathrm{~g})$ and triethylamine $\left(\mathrm{NEt}_{3}\right)$ (2.17 g) were added drop wise. The solution was initially left at $0{ }^{\circ} \mathrm{C}$ for $6 \mathrm{~h}$, and then at room temperature overnight. Samples were cleaned by sonication in DCM, acetone, methanol, and water for $10 \mathrm{~min}$ each, and dried with nitrogen.

The synthesis of the BPTCS initiator was carried out as detailed elsewhere ${ }^{41}$. To immobilize BPTCS on the surfaces, titanium samples were first activated by oxygen plasma ( $5 \mathrm{~min}, 100 \mathrm{~W})$. Then, titanium disks were immersed in a solution of BPTCS in toluene $(0.2 \% \mathrm{v} / \mathrm{v})$. The solution was left overnight at room temperature. Finally the samples were cleaned by sonication using toluene for $10 \mathrm{~min}$, and washed with methanol, acetone, and dried with nitrogen.

\subsubsection{Polymerization of brushes on titanium samples and peptide attachment}

The polymerization with DMA and APMA was performed in a glove box filled with argon. First, a solution composed by $1.68 \mathrm{mg}$ of $\mathrm{CuCl}_{2}, 10 \mathrm{mg}$ of $\mathrm{CuCl}$ and $75 \mu \mathrm{l}$ of 1,1,4,7,10,10hexamethyltriethylenetetramine (HMTETA) in $15 \mathrm{ml}$ of degassed water was prepared and stirred homogeneously. Then, the monomers DMA and APMA were added with a molar ratio of 5/1. The titanium samples were immersed in this mixture along with the addition of $2 \mu \mathrm{L}$ of soluble methyl 2-chloropropianate to initiate the polymerization. The ATRP was carried out at room temperature for $24 \mathrm{~h}$. The samples were washed in water and sonicated to remove any adhered copolymer on the surface.

Then titanium samples were immersed in $\mathrm{Et}_{3} \mathrm{~N}$ for 1 hour at room temperature to regenerate primary amine groups on the grafted copolymer chain, and ultrasonicated for 10 min with water and dried with nitrogen. The brushes were then immersed for $6 \mathrm{~h}$ at room temperature with iodoacetic acid N-hydroxysuccinimide in acetonitrile solution $(1 \mathrm{mg} / \mathrm{ml})$. Afterwards, samples were ultrasonicated with acetonitrile and acetone, and dried with nitrogen. The hLf1-11 peptide was dissolved in PBS at $\mathrm{pH} 8.5$ (adjusted with $\mathrm{Et}_{3} \mathrm{~N}$ ) and deposited onto the titanium samples $(100 \mu \mathrm{l} / \mathrm{disk}, 1 \mathrm{mg} / \mathrm{ml})$ overnight at room temperature. After peptide incubation, an excess of 2mercaptoethanol $(0.1 \mathrm{~g} / \mathrm{ml})$ was added for another $24 \mathrm{~h}$-period. Finally, samples were gently washed with PBS and dried with nitrogen.

The biofunctionalized samples, and their controls, are codified as follows:

Ti: Smooth titanium

Ti_A: Titanium + APTES

Ti_AI: Titanium + APTES + iodoacetyl crosslinker

Ti_AI_Lf: Titanium + APTES + iodoacetyl crosslinker + hLf1-11 peptide

Ti_ACo: Titanium + APTES + DMA-APMA copolymer

Ti_ACoI: Titanium + APTES + DMA-APMA copolymer + iodoacetyl crosslinker 
Ti_ACoI_Lf: Titanium + APTES + DMA-APMA copolymer + iodoacetyl crosslinker + hLf111 peptide

Ti_B: Titanium + BPTCS

Ti_BCo: Titanium + BPTCS + DMA-APMA copolymer

Ti_BCoI: Titanium + BPTCS + DMA-APMA copolymer + iodoacetyl crosslinker

Ti_BCoI_Lf: Titanium + BPTCS + DMA-APMA copolymer + iodoacetyl crosslinker + hLf1-11 peptide

\subsection{Physicochemical characterization of the surfaces}

\subsubsection{Contact angle analysis}

Hydrophilicity of the samples was determined by static contact angle (CA) measurements with ultrapure distilled water (Millipore Milli-Q, Merck Millipore Corporation, USA). To calculate the surface energy the apolar liquid diiodomethane was used in the following equation (Owens, Wendt, Rabel and Kaelble (OWRK)) method:

$$
\gamma_{L}(1+\cos \theta)=2\left(\left(\gamma_{L}^{d} \gamma_{S}^{d}\right)^{1 / 2}+\left(\gamma_{L}^{p} \gamma_{S}^{p}\right)^{1 / 2}\right)
$$

Where $\gamma_{L}^{\mathrm{d}}$ is the dispersive part of the liquid surface tension and $\gamma_{\mathrm{L}}^{\mathrm{p}}$ is the polar part of the liquid surface tension. $\Theta$ is the contact angle of the liquid $\mathrm{L}$ and solid $\mathrm{S}$.

Measurements were made with the sessile drop method (Contact Angle System OCA15 plus; Dataphysics, Germany). The volume was $3 \mu 1$ and the dosing rate was $1 \mu \mathrm{l} / \mathrm{min}$. All measurements were performed at $25^{\circ} \mathrm{C}$. Data was analyzed with SCA 20 software (Dataphysics). Three measurements were carried out for three different samples in each series.

\subsubsection{Roughness analysis}

The surface topography of the samples was analyzed with an optical profiling system Wyko NT1100 (Wyko NT1100, Veeco Instruments, USA) in white light vertical scanning interferometry mode, using a 5x objective lens. Data analysis was performed with Wyko Vision 232TM software (Veeco Instruments). Three samples for each condition were evaluated. For each sample, 3 measurements were acquired at different positions. The scanning areas were approximately $736 \times 480 \mu \mathrm{m}$. The following roughness parameters were studied: the arithmetic average height $\left(R_{\mathrm{a}}\right)$; the surface skewness $\left(\mathrm{R}_{\mathrm{sk}}\right)$, which measures the height distribution asymmetry of the profile; and the surface kurtosis $\left(\mathrm{R}_{\mathrm{ku}}\right)$, which represents the height distribution sharpness or 'peakedness' of the profile $e^{42,43}$.

\subsubsection{Polymer thickness by ellipsometry}

Variable-angle microscopy ellipsometry (W-VASE) was used to measure the dry layer thickness on silicon samples by an M-2000V spectroscopic ellipsometer (J.A.Woolham Co. Inc., Lincoln, 
NE, USA). Measurements were taken at $70^{\circ}$ of incident angle with an M-2000 $50 \mathrm{~W}$ quartz halogen light source. Data analysis was performed with WVASE32 analysis software (Lincoln, NE, USA)

\subsection{Chemical characterization}

\subsubsection{X-ray photoelectron spectroscopy assay}

X-ray photoelectron spectroscopy (XPS) was used to analyze the chemical composition of the surface of the samples. XPS spectra of the samples were acquired with an XR50 Mg anode source operating at 150W and a Phoibos 150 MCD-9 detector (D8 advance, SPECS Surface Nano Analysis GmbH, Germany). High resolution spectra were recorded with pass energy of 25 $\mathrm{eV}$ at $0.1 \mathrm{eV}$ steps at a pressure below $7.5 \cdot 10^{-9}$ mbar. Binding energies were referred to the $\mathrm{C} 1 \mathrm{~s}$ signal. Two samples were studied for each working condition.

\subsubsection{Peptide Grafting to Polymer Brushes}

The model used for the analysis of the density of peptide grafting from thickness measurements was developed by Gao et $a l^{29,31}$. Briefly, the graft density of the polymer layer was defined by the following basic equation:

$h_{b}=\frac{\sigma_{b}}{\rho_{b} \times N_{A}} \times M_{n b}$

where $\sigma_{b}$ is the graft density, $M_{n b}$ is the average molecular weight of the grafted chain, $h_{b}$ is the polymer layer thickness, the $\rho_{\mathrm{b}}$ is the density of the copolymer $(1.20 \mathrm{~g} / \mathrm{ml})^{38}$ and $\mathrm{N}_{\mathrm{A}}$ is the Avogadro's number.

Once the peptide is conjugated, different parameters can be calculated as follows:

- Amine saturation $\left(r_{p}\right.$, peptides/amine):

$r_{p}=\left(h-h_{b}-\frac{M_{i} \mp M_{E}}{r M_{D M A} M_{A P M A}} h_{b}\right) \frac{r_{D M A} M_{A P M A}}{\left(M_{p}-M_{E}\right) h_{b}}$

where $\mathrm{h}$ : brush thickness after peptide coating, $\mathrm{M}_{\mathrm{DMA}}$ : molecular weight of DMA, $\mathrm{M}_{\mathrm{APMA}}$ : molecular weight of APMA, r: brush DMA/APMA molar ratio, $\mathrm{M}_{\mathrm{i}}$ : one iodoacetic acid $\mathrm{N}$ hydroxysuccinimide group molecular weight on brush, $\mathrm{M}_{\mathrm{p}}$ : one peptide group molecular weight on brush (1374.59), ME: one 2-mercaptoethanol group molecular weight (78.13). However, if the effect of the iodoacetic and 2-mercaptoethanolon brush thickness increase is ignored, the equation can be simplified as below:

$r_{p}=\left(\mathrm{h}-\mathrm{h}_{\mathrm{b}}\right) \frac{\mathrm{rM}_{\mathrm{DMA}} \mathrm{M}_{\mathrm{APMA}}}{\mathrm{M}_{\mathrm{p}} \mathrm{h}_{\mathrm{b}}}$ 
- Peptide density $\left(\mathrm{W}_{\mathrm{p}}, \mu \mathrm{g} / \mathrm{cm}^{2}\right)$ :

$W_{p}=\frac{\mathrm{M}_{\mathrm{nb}} \mathrm{r}_{\mathrm{p}} \mathrm{M}_{\mathrm{p}} \sigma_{\mathrm{p}}}{\mathrm{rM}_{\mathrm{DMA}} \mathrm{M}_{\mathrm{APMA}} \mathrm{N}_{\mathrm{A}}}$

\subsection{Biological characterization of the surfaces}

\subsubsection{Cell culture of human foreskin fibroblasts (HFFs)}

HFFs were cultured in DMEM supplemented with $10 \%$ (v/v) fetal bovine serum (FBS), $1 \%$ (w/v) L-glutamine, $1 \%$ penicillin/streptomycin $(50 \mathrm{U} / \mathrm{ml}$ and $50 \mu \mathrm{g} / \mathrm{ml})$ at $37{ }^{\circ} \mathrm{C}$ in a humidified incubator and $5 \%(\mathrm{v} / \mathrm{v}) \mathrm{CO}_{2}$, renewed every 2 days. Cells between passage three and eight were used in all experiments. Confluent HFFs were detached from the culture flask by incubation with TrypLE for $5 \mathrm{~min}$. The HFFs solution was centrifuged at $300 \mathrm{~g}$ for $5 \mathrm{~min}$ and re-suspended in new culture medium.

\subsubsection{Cell cytotoxicity assay}

The indirect in vitro cytotoxicity of the functionalized surfaces was evaluated by incubating the samples will cell culture medium and analyzing the activity of the lactate dehydrogenase (LDH) enzyme of the extracts using the Cytotoxicity Detection Kit LDH. For that purpose, cell culture extracts were prepared according to ISO 10993-5, by incubating the samples in DMEM for $72 \mathrm{~h}$ at $37 \pm 2^{\circ} \mathrm{C}$. The surface area/volume of extraction medium ratio was $0.5 \mathrm{~cm}^{2} / 1 \mathrm{ml}$. The extracts were serially diluted with DMEM into five concentrations: 100\% (Complete), 50\% (1_1), 10\% $(1: 10), 1 \%(1: 100)$ and $0,1 \%\left(1 \_1000\right)$. Afterwards, HFFs were first cultured for $24 \mathrm{~h}$ to allow cell attachment in serum-containing DMEM in cell culture 96-well plates. Then, the medium was replaced by the extracts and samples incubated for another $24 \mathrm{~h}$. After this incubation period, the medium carefully aspired, and samples gently washed with PBS. Cells were then lysed with 200 $\mu 1 /$ well of M-PER ${ }^{\circledR}$ and the release of LDH spectrophotometrically measured at $490 \mathrm{~nm}$ with an ELx800 Universal Microplate Reader (Bio-Tek Instruments, Inc. Winooski, VT, USA). Cells cultured on tissue culture polystyrene (TCPS) were used as a low control sample and lysed cells cultured on TCPS were used as high control sample (maximum releasable LDH activity). The percentage of cytotoxicity was calculated as follows: $\%$ Cytotoxicity $=$ (experimental value - low control)/(high control-low control). Each condition was evaluated by triplicate.

\subsubsection{Cell proliferation assay}

Cell proliferation of cultured HFFs on the different surfaces was analyzed using the Cytotoxicity Detection Kit LDH. After 4 h, 1, 3 and 7 days of incubation with completed medium, cells were lysed with $200 \mu 1 /$ well of M-PER®. The release of $\mathrm{LDH}$, which is proportional to the number of proliferating cells, was measured spectrophotometrically as explained above. TCPS samples were used as positive controls. 


\subsection{Antimicrobial properties of the functionalized surfaces}

Bacterial assays were done with two oral bacterial strains: Streptococcus sanguinis and Lactobacillus salivarius. S. sanguinis was grown and maintained on Todd-Hewitt (TH) broth and L. salivarius on MRS broth. Cultures were incubated overnight at $37{ }^{\circ} \mathrm{C}$ before each assay. The optical density of each bacterial suspension was adjusted to $0.2 \pm 0.01$ at $600 \mathrm{~nm}$, giving approximately $1 \cdot 10^{8}$ colony forming units $(\mathrm{CFU}) / \mathrm{ml}$ for each strain. The assays were performed in static conditions due to the short testing time. All assays were performed using three replicates for each condition.

\subsubsection{Bacterial adhesion on titanium surfaces}

Functionalized samples were placed into 48 -well plates and incubated with $1 \mathrm{ml}$ of bacterial suspensions $\left(1 \cdot 10^{8} \mathrm{CFU} / \mathrm{ml}\right)$ for $2 \mathrm{~h}$ at $37^{\circ} \mathrm{C}$. After this time, the medium was aspired and samples washed twice with PBS. Adherent bacteria were detached by vortexing for $5 \mathrm{~min}$ the disks in $1 \mathrm{ml}$ of PBS. These bacteria were then seeded using serial dilutions on TH agar plates for S. sanguinis and MRS agar plates for L. salivarius. The plates were then incubated at $37{ }^{\circ} \mathrm{C}$ for $24 \mathrm{~h}$ and the resulting colonies counted. Alternatively, for slow growing colonies the plates were incubated for an extra $24 \mathrm{~h}$ period, and the number of bacterial colonies counted again.

\subsubsection{Viability of bacteria on modified samples}

A LIVE/DEAD BackLight bacterial viability kit was used. The red-fluorescent nucleic acid staining agent propidium iodide, which only penetrates damaged cell membrane, was used to label dead bacterial cells on the modified samples. SYTO ${ }^{\circledR} 9$ green-fluorescent nucleic acid staining agent, which can penetrate cells both with intact and damaged membranes, was used to label all bacterial cells. $1 \mathrm{ml}$ of bacterial suspension $\left(1 \cdot 10^{8}\right.$ cells $\left./ \mathrm{ml}\right)$ was seeded onto titanium surfaces and incubated at $37{ }^{\circ} \mathrm{C}$ for $2 \mathrm{~h}$. The supernatant was then removed and samples were washed with PBS two times. Samples were finally transferred into a 48 -well microtiter plate (Nunc, Thermo Scientific, Waltham, MA, USA) and incubated with $200 \mu \mathrm{l}$ of a solution containing the two dyes at room temperature in the dark for $15 \mathrm{~min}$. The dyes-containing solution was prepared by adding $3 \mu \mathrm{l}$ of $\mathrm{SYTO}^{\circledR}$ and $3 \mu \mathrm{l}$ of propidium iodide to $2 \mathrm{ml}$ of PBS buffer.

Confocal laser scanning microscopy CLSM images of the attached bacteria were acquired by the software EZ-C1 v3.40 build 691(Nikon), and the specimens were observed by using a 20 lens. All images were acquired at five random positions of the surfaces and a stack of 40 slices (each 1 $\mathrm{mm}$ thick) were scanned.The confocal LIVE/DEAD images were analyzed and quantified by using the MeVisLab package (available from www.mevislab.de/). The volume ratio of red fluorescence (dead cells) vs. green and red fluorescence (dead and live cells) indicated the portion of killed cells for each treatment.

volume ratio of dead cells $=\frac{\text { volume of red bacterial }}{\text { volume of red bacteria }+ \text { volume of green bacteria }}$ 


\subsubsection{Evaluation of biofilm formation on titanium surfaces}

Samples were immersed in $1 \mathrm{ml}$ of bacterial suspensions for $2 \mathrm{~h}$ as previously explained. Next, the disks were cleaned twice with medium, and bacteria were allowed to grow in $1 \mathrm{ml}$ of clean medium for $24 \mathrm{~h}$ at $37^{\circ} \mathrm{C}$. After this treatment, titanium disks were washed twice with PBS and $200 \mu 1$ of BacTiter-Glo Reagent were added to each sample. This reagent was left to react in the dark at room temperature for $15 \mathrm{~min}$. Finally, a volume of $100 \mu \mathrm{l}$ from each sample was transferred to an opaque-walled 96-well plate and its luminescence measured with a multimode microplate reader.

\subsection{Stability studies}

To determine the stability of the antibacterial coatings and their effectiveness in reducing bacterial adhesion, treated samples were immersed in PBS and subjected to ultrasonication for 2 h. Subsequently, a comparison between sonicated samples and untreated disks was analyzed by contact angle, ellipsometry, as well as bacterial adhesion and biofilm formation assays.

\subsection{Statistical analysis}

A non-parametric U Mann-Whitney test was used to analyze significant differences in all assays. Significance level was set at a P value $<0.05$. Data were analyzed with IBM SPSS Statistics 20 software (Armonk, NY, USA). 


\section{RESULTS}

\subsection{Contact angle analysis}

Table 1. Values of contact angle (CA), surface free energy (SFE), and its dispersive (DISP) and polar (POL) components, for each surface treatment. Statistically significant differences versus control Ti are indicated with an 'a, , versus Ti_A sample with a ${ }^{\text {b' }}$, versus Ti_ACo samples with a ${ }^{\text {cc }}$, and versus Ti_BCo samples with $\mathrm{a}^{\text {ad, }}(\mathrm{P}<0.05)$. Statistically significant differences versus samples without $2 \mathrm{~h}$ of sonication are indicated with an 'e, $(\mathrm{P}<0.05)$.

\begin{tabular}{|c|c|c|c|c|c|}
\hline & \multicolumn{4}{|c|}{ Before $2 \mathrm{~h}$ sonication } & \multirow{2}{*}{$\frac{\text { After } 2 \text { h sonication }}{\mathrm{CA}\left({ }^{\circ}\right)}$} \\
\hline & $\mathrm{CA}\left({ }^{\circ}\right)$ & $\operatorname{SFE}\left(\mathrm{mJ} / \mathrm{m}^{2}\right)$ & $\operatorname{DISP}\left(\mathrm{mJ} / \mathrm{m}^{2}\right)$ & $\operatorname{POL}\left(\mathrm{mJ} / \mathrm{m}^{2}\right)$ & \\
\hline $\mathbf{T i}$ & $68.7 \pm 2.7$ & $47.5 \pm 2.4$ & $39.4 \pm 2.2$ & $8.1 \pm 1.2^{\mathrm{a}}$ & $67.4 \pm 3.0$ \\
\hline Ti_A & $74.0 \pm 2.0^{\mathrm{a}}$ & $44.2 \pm 1.4^{\mathrm{a}}$ & $35.1 \pm 9.9$ & $5.5 \pm 2.2^{\mathrm{a}}$ & $70.5^{\mathrm{e}} \pm 4.1$ \\
\hline Ti_AI & $68.2 \pm 3.5^{\mathrm{b}}$ & $44.2 \pm 1.8^{\mathrm{a}}$ & $34.2 \pm 0.8^{\mathrm{a}, \mathrm{b}}$ & $10.1 \pm 1.9^{\mathrm{a}, \mathrm{b}}$ & \\
\hline Ti_AI_Lf & $63.5 \pm 2.3^{\mathrm{a}, \mathrm{b}}$ & $49.2 \pm 2.0^{\mathrm{b}}$ & $37.3 \pm 1.8^{\mathrm{a}}$ & $12.0 \pm 1.5^{\mathrm{a}, \mathrm{b}}$ & $61.2 \pm 2.7$ \\
\hline Ti_ACo & $45.7 \pm 3.1^{\mathrm{a}}$ & $59.7 \pm 1.9^{\mathrm{a}}$ & $38.7 \pm 1.4$ & $21.1 \pm 1.9^{\mathrm{a}}$ & $51.3^{\mathrm{e}} \pm 2.7$ \\
\hline Ti_ACoI & $55.1 \pm 2.4^{\mathrm{a}, \mathrm{c}}$ & $55.0 \pm 1.2^{\mathrm{a}, \mathrm{c}}$ & $39.7 \pm 1.0$ & $15.2 \pm 1.6^{\mathrm{a}, \mathrm{c}}$ & \\
\hline Ti ACoI Lf & $64.6 \pm 2.7^{\mathrm{a}, \mathrm{c}}$ & $47.0 \pm 1.8^{\mathrm{c}}$ & $35.5 \pm 1.3^{\mathrm{a}, \mathrm{c}}$ & $11.5 \pm 1.5^{\mathrm{a}, \mathrm{c}}$ & $65.9 \pm 2.4$ \\
\hline Ti_B & $94.8 \pm 5.4^{\mathrm{a}}$ & $41.0 \pm 2.6^{\mathrm{a}}$ & $40.5 \pm 2.8$ & $0.6 \pm 0.9^{\mathrm{a}}$ & $75.5^{\mathrm{e}} \pm 2.4$ \\
\hline Ti_BCo & $54.5 \pm 3.5^{\mathrm{a}}$ & $56.8 \pm 2.3^{\mathrm{a}}$ & $42.2 \pm 2.8^{\mathrm{a}, \mathrm{d}}$ & $14.6 \pm 2.3^{\mathrm{a}}$ & $62.0^{\mathrm{e}} \pm 1.8$ \\
\hline Ti_BCoI & $65.0 \pm 3.0^{\mathrm{a}, \mathrm{d}}$ & $49.0 \pm 2.2^{\mathrm{d}}$ & $38.9 \pm 2.0^{\mathrm{d}}$ & $10.2 \pm 1.7^{\mathrm{a}, \mathrm{d}}$ & \\
\hline Ti_BCoI_Lf & $72.1 \pm 5.0^{\mathrm{a}, \mathrm{d}}$ & $46.3 \pm 2.3^{\mathrm{d}}$ & $37.4 \pm 6.6^{\mathrm{d}}$ & $6.6 \pm 2.6^{\mathrm{a}, \mathrm{d}}$ & $66.7^{\mathrm{e}} \pm 3.6$ \\
\hline
\end{tabular}

The values of contact angle and surface energy measured for all functionalized samples and their controls are shown in Table 1. Silanization of titanium surfaces slightly increases contact angle values (Ti_A and Ti_B) together with a decrease in SFE. Moreover, the CA values obtained by using BPTCS (Ti_B) were roughly higher than when using APTES (Ti_A) as linking agent. Covalent attachment of hLf1-11 onto aminosilanized surfaces (Ti_AI_Lf) reduced significantly CA values on these samples, yielding an increase in wettability compared to smooth titanium surfaces (Ti). Polymerization of silanized samples by ATRP (Ti_ACo and Ti_BCo) drastically reduced $\mathrm{CA}$ values and provoked a significant increase in the polar component of the SFE. In contrast, subsequent covalent immobilization of hLf1-11 on polymerized substrates increased CA values. Comparing CA values of peptide-biofunctionalized samples, the wettability of the samples modified via polymer brushes was similar (Ti_ACoI_Lf) or statistically higher (Ti_BCoI_Lf) than that of simply aminosilanized samples (Ti_AI_Lf).

To study the stability of coating systems, representative samples were immersed in PBS and subjected to ultrasonication for $2 \mathrm{~h}$. After this treatment, the CA of silanized samples decreased. This effect was in particular remarkable for samples silanized with BPTCS (Ti_B). CA values of the polymeric brushes were also modified (Ti_ACo and Ti_BCo). On samples functionalized with hLf1-11, statistically significant differences were observed when using BPTCS (Ti_ BCoI_Lf) but not when using APTES (Ti_AI_Lf and Ti_ACoI_Lf). 


\subsection{Roughness analysis}

Table 2. Roughness values (mean \pm standard deviation) for each surface treatment. Statistically significant differences versus control Ti are indicated with an 'a, , versus Ti_A sample with a 'b' and versus Ti_ACo samples with a "c, $(\mathrm{P}<0.05)$.

\begin{tabular}{llll}
\hline & $\mathbf{R}_{\mathbf{a}}[\mathbf{n m}]$ & $\mathbf{R}_{\text {ku }}[\mathbf{n m}]$ & $\mathbf{R}_{\text {sk }}[\mathbf{n m}]$ \\
\hline Ti & $25.1 \pm 5.4$ & $4.1 \pm 1.8$ & $0,8 \pm 0,6$ \\
Ti_A & $19.5 \pm 3.9^{\mathrm{a}}$ & $6.4 \pm 2.5^{\mathrm{a}}$ & $0.4 \pm 0.5$ \\
Ti_AI & $29.6 \pm 2.5^{\mathrm{a}, \mathrm{b}}$ & $6.0 \pm 1.5^{\mathrm{a}}$ & $1.5 \pm 0.7^{\mathrm{b}}$ \\
Ti_AI_Lf & $29.2 \pm 4.1^{\mathrm{b}}$ & $6.6 \pm 2.1^{\mathrm{a}}$ & $3.2 \pm 1.3^{\mathrm{a}, \mathrm{b}}$ \\
Ti_ACo & $24.7 \pm 6.2$ & $4.1 \pm 1.8$ & $1.1 \pm 0.8$ \\
Ti_ACOI & $31.2 \pm 4.4^{\mathrm{a}, \mathrm{c}}$ & $6.0 \pm 1.8^{\mathrm{c}}$ & $1.4 \pm 0.8$ \\
Ti_ACoI_Lf & $30.5 \pm 3.1^{\mathrm{a}, \mathrm{c}}$ & $6.1 \pm 2.0^{\mathrm{c}}$ & $1.9 \pm 1.0^{\mathrm{a}, \mathrm{c}}$ \\
Ti_B & $30.1 \pm 3.9^{\mathrm{a}}$ & $5.8 \pm 1.2^{\mathrm{a}}$ & $2.3 \pm 1.0^{\mathrm{a}}$ \\
Ti_BCo & $32.7 \pm 3.6^{\mathrm{a}}$ & $7.2 \pm 1.6^{\mathrm{a}}$ & $3.0 \pm 1.2^{\mathrm{a}}$ \\
Ti_BCoI & $30.9 \pm 3.3^{\mathrm{a}}$ & $8.0 \pm 1.8^{\mathrm{a}}$ & $1.8 \pm 0.9^{\mathrm{a}}$ \\
Ti_BCoI_Lf & $30.4 \pm 3.5^{\mathrm{a}}$ & $7.1 \pm 1.7^{\mathrm{a}}$ & $2.0 \pm 1.3^{\mathrm{a}}$ \\
\hline
\end{tabular}

Table 2 shows the values of three different roughness parameters $\left(R_{a}, R_{k u}\right.$ and $\left.R_{s k}\right)$. Peptide attachment though strategy 1 (silanization with APTES) (Ti_AI_Lf) did not result in a significant difference of $R_{a}$ in comparison with smooth titanium (Ti). However, the other two strategies (grafting with polymer brushes) (Ti_ACoI_Lf and Ti_BCoI_Lf) resulted in higher $\mathrm{R}_{\mathrm{a}}$ values than control titanium after polymerization. For the scanned areas, both $R_{k u}$ and $R_{s k}$ values were significantly higher in almost all conditions compared to control titanium.

\subsection{Thickness of the coatings by ellipsometry measurements}

Table 3. Thickness values (mean \pm standard deviation) for each surface treatment. Statistically significant differences versus control Ti_A are indicated with an ${ }^{\mathrm{a} a}$, , versus Ti_B sample with a ${ }^{\mathrm{b}}$, , versus Ti_ACo sample with a ${ }^{\text {c, }}$ and versus Ti_BCo samples with $a^{\text {dd, }}$. Statistically significant differences before and after sonication are indicated with a "*" $(\mathrm{P}<0.05)$.

Thickness (nm)

\begin{tabular}{lcc}
\hline & Before sonication & After 2 h sonication \\
\hline Ti_A & $3.6 \pm 0.9$ & $1.8^{*} \pm 0.1$ \\
Ti_AI & $3.9 \pm 0.7$ & \\
Ti_AI_Lf & $11.6 \pm 2.5^{\mathrm{a}}$ & $6.8^{*} \pm 0.5$ \\
Ti_ACo & $23.7 \pm 2.8^{\mathrm{a}}$ & $14.5 \pm 0.4$ \\
Ti_ACoI & $23.0 \pm 3.3^{\mathrm{a}}$ & \\
Ti_ACoI_Lf & $37.7 \pm 2.1^{\mathrm{a}, \mathrm{c}}$ & $19.3^{*} \pm 0.3$ \\
Ti_B & $1.8 \pm 0.7$ & $1.9 \pm 0.1$ \\
Ti_BCo & $25.0 \pm 2.2^{\mathrm{b}}$ & $13.8^{*} \pm 0.6$ \\
Ti_BCoI & $24.4 \pm 2.2^{\mathrm{b}}$ & \\
Ti_BCoI_Lf & $35.9 \pm 3.2^{\mathrm{b}, \mathrm{d}}$ & $21.3^{*} \pm 0.8$ \\
\hline
\end{tabular}


Simple silanization and ATRP polymerization on titanium showed marked differences in the thickness of the coating layers (Table 3). In particular, the polymer thickness obtained after silanization (Ti_A and Ti_B) was significantly increased from 1.8-3.6 nm to values higher than $20 \mathrm{~nm}$ when the ATRP was performed (Ti_ACo and Ti_BCo). Addition of the crosslinker had a negligible effect; however, peptide attachment resulted in a pronounced increase in the samples thickness. After peptide binding, the two strategies based on ATRP yielded the same layer thickness (Ti_ACoI_Lf and Ti_BCoI_Lf), with values higher than those obtained with strategy 1 (Ti_AI_Lf) by a factor of 2. In general, sonication of the samples was accompanied by a significant thickness reduction of the polymeric layer.

\subsection{Chemical composition by X-ray photoelectron spectroscopy}

Table 4. Chemical composition (atomic percentages, \%) and $\mathrm{Si} / \mathrm{Ti}$ and $\mathrm{S} / \mathrm{Ti}$ relative atomic ratios.

\begin{tabular}{lcccccccc}
\hline & C 1s \% & N 1s \% & O 1s \% & S 2p \% & Si 2p \% & Ti 2p \% & S/Ti & Si/Ti \\
\hline Ti & $36.3 \pm 7.3$ & $2.3 \pm 1.6$ & $47.9 \pm 6.4$ & $0.2 \pm 0.1$ & $1.1 \pm 0.7$ & $13.2 \pm 3.3$ & $0.01 \pm 0.01$ & $0.1 \pm 0.8$ \\
Ti_A & $45.1 \pm 6.7$ & $5.1 \pm 2.1$ & $34.3 \pm 7.6$ & $0.4 \pm 0.1$ & $10.2 \pm 0.4$ & $5.2 \pm 1.3$ & $0.07 \pm 0.02$ & $2.0 \pm 0.6$ \\
Ti_AI & $49.3 \pm 0.7$ & $3.4 \pm 0.2$ & $36.9 \pm 0.4$ & $0.6 \pm 0.05$ & $3.2 \pm 0.3$ & $6.7 \pm 0.3$ & $0.09 \pm 0.01$ & $0.5 \pm 0.07$ \\
Ti_AI_Lf & $57.4 \pm 2.5$ & $11.5 \pm 2.4$ & $26.0 \pm 1.5$ & $0.9 \pm 0.2$ & $1.6 \pm 0.4$ & $2.6 \pm 1.0$ & $0.4^{\mathrm{a}} \pm 0.06$ & $0.6 \pm 0.07$ \\
Ti_ACo & $55.9 \pm 0.03$ & $7.1 \pm 0.1$ & $28.2 \pm 0.7$ & $0.3 \pm 0.1$ & $4.7 \pm 0.2$ & $4.5 \pm 0.4$ & $0.07 \pm 0.02$ & $1.1 \pm 0.04$ \\
Ti_ACoI & $56.0 \pm 2.4$ & $5.5 \pm 0.4$ & $29.8 \pm 3.2$ & $0.3 \pm 0.1$ & $4.3 \pm 0.5$ & $4.7 \pm 0.1$ & $0.06 \pm 0.02$ & $0.9 \pm 0.1$ \\
Ti_ACoI_Lf & $58.6 \pm 1.7$ & $13.1 \pm 6.8$ & $23.9 \pm 7.4$ & $1.3 \pm 0.4$ & $1.0 \pm 0.1$ & $1.6 \pm 0.8$ & $1.3^{\mathrm{b}} \pm 0.4$ & $0.7 \pm 0.3$ \\
Ti_B & $59.0 \pm 1.8$ & $5.7 \pm 3.5$ & $25.6 \pm 0.7$ & $0.2 \pm 0.1$ & $7.5 \pm 1.9$ & $2.5 \pm 0.1$ & $0.06 \pm 0.04$ & $2.9 \pm 0.8$ \\
Ti_BCo & $75.4 \pm 0.6$ & $11.0 \pm 0.2$ & $12.5 \pm 0.5$ & $0.03 \pm 0.0$ & $0.9 \pm 0.0$ & $0.8 \pm 0.2$ & $0.04 \pm 0.0$ & $1.2 \pm 0.3$ \\
Ti_BCoI & $70.8 \pm 0.2$ & $11.5 \pm 0.2$ & $16.7 \pm 0.4$ & $0.1 \pm 0.0$ & $0.6 \pm 0.07$ & $1.0 \pm 0.01$ & $0.1 \pm 0.0$ & $0.6 \pm 0.07$ \\
Ti_BCoI_Lf & $71.8 \pm 1.0$ & $12.1 \pm 1.5$ & $13.7 \pm 0.1$ & $0.9 \pm 0.02$ & $0.7 \pm 0.1$ & $0.8 \pm 0.1$ & $1.1^{\mathrm{c}} \pm 0.2$ & $0.8 \pm 0.04$ \\
\hline
\end{tabular}

The atomic composition of all surfaces was studied by means of XPS (Table 4). For all strategies, silanization and peptide attachment resulted in an increase in the percentage of $\mathrm{C} 1 \mathrm{~s}$ and $\mathrm{N} \mathrm{1s}$, and a reduction in $\mathrm{O}$ 1s and Ti $2 \mathrm{p}$ signals, in comparison with control titanium. Consistent with the results observed by ellipsometry, these effects were more pronounced for strategies 2 and 3.

Silanization, a crucial step in all three strategies, was characterized by the presence of silicon on the samples $(10.2 \%$ for Ti_A and $7.5 \%$ for Ti_B). According to the atomic ratios \%Si $(-99.3$ $\mathrm{eV}) / \% \mathrm{Ti}(454.1 \mathrm{eV})$, silanization seemed to be slightly more efficient for BPTCS than for APTES (Si/Ti ratio of 2.0 for Ti_A; and 2.9 for Ti_B), although these values were not statistically different. Besides the aforementioned changes in chemical composition, the presence of sulfur ( $\mathrm{S} 2 \mathrm{p}$ ) is a clear indicator of the successful attachment of the hLf1-11 peptide on the surfaces. Noteworthy, calculation of the atomic ratio $\% \mathrm{~S}(\sim 164 \mathrm{eV}) / \% \mathrm{Ti}(-454.1 \mathrm{eV})$ indicated that ATRP method allowed the conjugation of about 3-fold more peptide than standard silanization (S/Ti ratio of 0.4 for Ti_AI_Lf; 1.3 for Ti_ACoI_Lf; and 1.1 for Ti_BCoI_Lf). 
Table 5. Deconvolution of $\mathrm{C} 1 \mathrm{~s}$ and $\mathrm{O}$ 1s high resolution spectra: XPS binding energies (eV) and relative intensities (percentages, \%).

\begin{tabular}{|c|c|c|c|c|c|c|}
\hline & \multicolumn{3}{|c|}{$01 \mathrm{~s}$} & \multicolumn{3}{|c|}{$C 1 s$} \\
\hline & Bond State & Binding Energy (eV) & $\% 01 s$ & Bond State & Binding Energy (eV) & $\% C 1 s$ \\
\hline$T i$ & $\begin{array}{l}\mathrm{TiO}_{2} \\
\mathrm{OH}\end{array}$ & $\begin{array}{c}529.8 \pm 0.2 \\
531.1 \pm 0.08\end{array}$ & $\begin{array}{l}52.1 \pm 4.4 \\
47.9 \pm 4.4\end{array}$ & $\begin{array}{c}\mathrm{C}-\mathrm{C} \\
\mathrm{C}-\mathrm{OH} \\
\mathrm{C}=\mathrm{O} / \mathrm{O}-\mathrm{C}=\mathrm{O}\end{array}$ & $\begin{array}{l}284,7 \pm 7,0 \\
286,0 \pm 0,2 \\
288,1 \pm 0,5\end{array}$ & $\begin{array}{c}72,3 \pm 0,9 \\
24,9 \pm 4,4 \\
2,8 \pm 3,5\end{array}$ \\
\hline$\overline{T i \_A}$ & $\begin{array}{c}\mathrm{TiO}_{2} \\
\mathrm{OH} \\
\mathrm{Ti}-\mathrm{O}-\mathrm{Si}\end{array}$ & $\begin{array}{l}529.6 \pm 0.1 \\
530.6 \pm 0.1 \\
531.8 \pm 0.2\end{array}$ & $\begin{array}{c}40.9 \pm 7.5 \\
3.6 \pm 0.9 \\
49.6 \pm 5.6\end{array}$ & $\begin{array}{c}C-\mathrm{C} \\
C-\mathrm{N} / \mathrm{C}-\mathrm{OR} / \mathrm{C}-\mathrm{OH} \\
\mathrm{C}=\mathrm{O} / \mathrm{O}-\mathrm{C}=\mathrm{O} / \mathrm{O}=\mathrm{C}-\end{array}$ & $\begin{array}{c}284,7 \pm 0,02 \\
286,1 \pm 0,01 \\
288,1 \pm 0,2\end{array}$ & $\begin{array}{c}66,3 \pm 3,6 \\
29,4 \pm 2,7 \\
4,3 \pm 0,9\end{array}$ \\
\hline Ti_Al & $\begin{array}{c}\mathrm{TiO}_{2} \\
\mathrm{Ti}-\mathrm{O}-\mathrm{Si}\end{array}$ & $\begin{array}{c}529.5 \pm 0.01 \\
531.6 \pm 0.1\end{array}$ & $\begin{array}{l}40.4 \pm 1.6 \\
58.0 \pm 1.2\end{array}$ & $\begin{array}{c}C-C \\
C-N / C-O R / C-O H \\
C=O / O-C=O / O=C-\end{array}$ & $\begin{array}{l}284,7 \pm 0,1 \\
285,7 \pm 0,8 \\
288,3 \pm 0,01\end{array}$ & $\begin{array}{l}75,8 \pm 2,5 \\
10,4 \pm 3,1 \\
13,8 \pm 0,6\end{array}$ \\
\hline$\overline{T i \_A I \_L f}$ & $\begin{array}{c}\mathrm{TiO}_{2} \\
\mathrm{OCN} / \mathrm{COOH} / \mathrm{OH} \\
\mathrm{Ti}-\mathrm{O}-\mathrm{Si}\end{array}$ & $\begin{array}{l}528.6 \pm 0.2 \\
529.8 \pm 0.3 \\
531.7 \pm 0.3\end{array}$ & $\begin{array}{l}0,6 \pm 0,03 \\
16.5 \pm 7.0 \\
84.7 \pm 8.3\end{array}$ & $\begin{array}{c}C-C \\
C-O H /(C-C) n / C-S \\
C=O / O-C=O / O=C-\end{array}$ & $\begin{array}{l}284,7 \pm 0,1 \\
285,9 \pm 0,1 \\
287,9 \pm 0,1\end{array}$ & $\begin{array}{l}54,8 \pm 5,2 \\
22,2 \pm 1,0 \\
23,0 \pm 4,2\end{array}$ \\
\hline$T$ Ti_ACo & $\begin{array}{c}\mathrm{TiO}_{2} \\
\mathrm{OCN} / \mathrm{COOH} / \mathrm{OH} \\
\mathrm{Ti}-\mathrm{O}-\mathrm{Si} \\
\mathrm{H}_{2} \mathrm{O}\end{array}$ & $\begin{array}{c}529.4 \pm 0.03 \\
530.7 \pm 0.1 \\
532.2 \pm 0.1 \\
533.5 \pm 0.04\end{array}$ & $\begin{array}{c}21.6 \pm 1.4 \\
65.1 \pm 3.4 \\
9.2 \pm 0.1 \\
4.1 \pm 0.05\end{array}$ & $\begin{array}{c}C-\mathrm{C} \\
\mathrm{C}-\mathrm{N} / \mathrm{C}-\mathrm{OR} / \mathrm{C}-\mathrm{OH} \\
\mathrm{C}=\mathrm{O} / \mathrm{O}-\mathrm{C}=\mathrm{O} / \mathrm{O}=\mathrm{C}- \\
\wedge \prime\end{array}$ & $\begin{array}{l}284,7 \pm 0,1 \\
285,7 \pm 0,1 \\
286,6 \pm 0,2\end{array}$ & $\begin{array}{c}60,1 \pm 5,0 \\
7,5 \pm 0,7 \\
32,4 \pm 5,8\end{array}$ \\
\hline$\overline{T i \_A C o l}$ & $\begin{array}{c}\mathrm{TiO}_{2} \\
\mathrm{OCN} / \mathrm{COOH} / \mathrm{OH} \\
\mathrm{Ti}-\mathrm{O}-\mathrm{Si}\end{array}$ & $\begin{array}{c}529.3 \pm 0.2 \\
530.8 \pm 0.4 \\
531.6 \pm 0\end{array}$ & $\begin{array}{l}13.8 \pm 0.3 \\
60.6 \pm 7.2 \\
25.3 \pm 7.0\end{array}$ & $\begin{array}{c}C-\mathrm{C} \\
C-\mathrm{N} / \mathrm{C}-\mathrm{OR} / \mathrm{C}-\mathrm{OH} \\
\mathrm{C}=\mathrm{O} / \mathrm{O}-\mathrm{C}=\mathrm{O} / \mathrm{O}=\mathrm{C}-\end{array}$ & $\begin{array}{c}284,7 \pm 0,01 \\
285,9 \pm 0,04 \\
287,6 \pm 0,4\end{array}$ & $\begin{array}{c}60,6 \pm 8,7 \\
7,6 \pm 1,6 \\
27,1 \pm 0,5\end{array}$ \\
\hline Ti_ACol_Lf & $\begin{array}{c}\mathrm{TiO}_{2} \\
\mathrm{OCN} / \mathrm{COOH} / \mathrm{OH} \\
\mathrm{Ti}-\mathrm{O}-\mathrm{Si}\end{array}$ & $\begin{array}{c}529.3 \pm 0.08 \\
530.9 \pm 0.1 \\
532.3 \pm 0.04\end{array}$ & $\begin{array}{c}5.1 \pm 3.0 \\
74.2 \pm 12.1 \\
20.1 \pm 9.3\end{array}$ & $\begin{array}{c}C-C \\
C-O H /(C-C) n / C-S \\
C=O / O-C=O / O=C-\end{array}$ & $\begin{array}{c}284,7 \pm 0,03 \\
285,5 \pm 0,7 \\
287,6 \pm 0,07\end{array}$ & $\begin{array}{c}59,1 \pm 5,7 \\
9,0 \pm 4,4 \\
30,9 \pm 1,3\end{array}$ \\
\hline$T i \_B$ & $\begin{array}{c}\mathrm{TiO}_{2} \\
\mathrm{OCN} / \mathrm{COOH} / \mathrm{OH} \\
\mathrm{Ti}-\mathrm{O}-\mathrm{Si}\end{array}$ & $\begin{array}{c}529.0 \pm 0.2 \\
530.0 \pm 0.03 \\
532.5 \pm 0.2\end{array}$ & $\begin{array}{c}15.3 \pm 1.6 \\
7.4 \pm 3.7 \\
70.4 \pm 4.4\end{array}$ & $\begin{array}{c}C-\mathrm{C} \\
C-\mathrm{N} / \mathrm{C}-\mathrm{OR} / \mathrm{C}-\mathrm{OH} \\
\mathrm{C}=\mathrm{O} / \mathrm{O}-\mathrm{C}=\mathrm{O} / \mathrm{O}=\mathrm{C}-\end{array}$ & $\begin{array}{r}284,7 \pm 0,01 \\
286,0 \pm 0,5 \\
287,8 \pm 1,7\end{array}$ & $\begin{array}{c}73,3 \pm 7,7 \\
24,3 \pm 6,7 \\
2,4 \pm 1,0\end{array}$ \\
\hline$T i \_B C o$ & $\begin{array}{c}\mathrm{TiO}_{2} \\
\mathrm{OCN} / \mathrm{COOH} / \mathrm{OH} \\
\mathrm{Ti}-\mathrm{O}-\mathrm{Si}\end{array}$ & $\begin{array}{c}528.9 \pm 0.6 \\
530.7 \pm 0.09 \\
531.5 \pm 0.04\end{array}$ & $\begin{array}{c}6.8 \pm 2.9 \\
43.3 \pm 2.6 \\
49.9 \pm 18.3\end{array}$ & $\begin{array}{c}C-\mathrm{C} \\
C-\mathrm{N} / \mathrm{C}-\mathrm{OR} / \mathrm{C}-\mathrm{OH} \\
\mathrm{C}=\mathrm{O} / \mathrm{O}-\mathrm{C}=\mathrm{O} / \mathrm{O}=\mathrm{C}-\end{array}$ & $\begin{array}{l}284,5 \pm 0,2 \\
285,4 \pm 0,2 \\
287,2 \pm 0,1\end{array}$ & $\begin{array}{c}66,6 \pm 10,6 \\
15,4 \pm 7,1 \\
18,0 \pm 3,5\end{array}$ \\
\hline$\overline{T i \_B C o l}$ & $\begin{array}{c}\mathrm{TiO}_{2} \\
\mathrm{OCN} / \mathrm{COOH} / \mathrm{OH} \\
\mathrm{Ti}-\mathrm{O}-\mathrm{Si}\end{array}$ & $\begin{array}{l}528.1 \pm 0.06 \\
530.1 \pm 0.06 \\
532.1 \pm 0.03\end{array}$ & $\begin{array}{l}0.9 \pm 0.03 \\
59.3 \pm 0.4 \\
39.7 \pm 0.4\end{array}$ & $\begin{array}{c}C-\mathrm{C} \\
C-\mathrm{N} / \mathrm{C}-\mathrm{OR} / \mathrm{C}-\mathrm{OH} \\
\mathrm{C}=\mathrm{O} / \mathrm{O}-\mathrm{C}=\mathrm{O} / \mathrm{O}=\mathrm{C}-\end{array}$ & $\begin{array}{c}284,7 \pm 0,06 \\
286,1 \pm 0,2 \\
287,4 \pm 0,6\end{array}$ & $\begin{array}{l}64,4 \pm 0,9 \\
13,1 \pm 1,2 \\
22,8 \pm 4,4\end{array}$ \\
\hline Ti_BCol_Lf & $\begin{array}{c}\mathrm{TiO}_{2} \\
\mathrm{OCN} / \mathrm{COOH} / \mathrm{OH} \\
\mathrm{Ti}-\mathrm{O}-\mathrm{Si} \\
\mathrm{H}_{2} \mathrm{O}\end{array}$ & $\begin{array}{c}528.2 \pm 0.2 \\
530.6 \pm 0.04 \\
531.6 \pm 0.1 \\
533.1 \pm 0.2\end{array}$ & $\begin{array}{c}1.6 \pm 0.1 \\
68.8 \pm 5.6 \\
25.7 \pm 4.3 \\
4.0 \pm 1.5\end{array}$ & $\begin{array}{c}C-C \\
C-O H /(C-C) n / C-S \\
C=O / O-C=O / O=C- \\
\wedge \text {, }\end{array}$ & $\begin{array}{l}284,4 \pm 0,1 \\
285,4 \pm 0,2 \\
287,1 \pm 0,1\end{array}$ & $\begin{array}{l}59,5 \pm 22,1 \\
15,4 \pm 27,0 \\
29,03 \pm 4,9\end{array}$ \\
\hline
\end{tabular}

Deconvolution of $\mathrm{C} 1 \mathrm{~s}$ and $\mathrm{O} 1 \mathrm{~s}$ high resolution XPS spectra are shown in Table 5. The C 1s signal showed three peaks at binding energies of approximately 285 (aliphatic C-C), 286 (polar C$\mathrm{O} / \mathrm{C}-\mathrm{N}$ groups) and 287-288 eV (CO, carbonyl groups). Peptide immobilization via APTES 
silanization resulted in a significant increase in the high-energy component of $\mathrm{C} 1 \mathrm{~s}$ compared to controls (Ti_AI_Lf vs. Ti, Ti_A and Ti_AI). The same effect was observed on samples after the ATRP (Ti_ACo and Ti_BCo) and subsequent peptide grafting (Ti_ACoI_Lf and Ti_BCoI_Lf).

The functionalization strategies were further characterized by the analysis of $\mathrm{O} 1 \mathrm{~s}$. The $\mathrm{O} 1 \mathrm{~s}$ peak displayed three main contributions at binding energies of approximately 529-530 $\left(\mathrm{TiO}_{2}\right)$, 530-531 (OH and $\mathrm{CO}$ groups) and $532 \mathrm{eV}$ (Ti-O-Si). A minor, fourth contribution at higher energies ( $\geq 533 \mathrm{eV}, \mathrm{H}_{2} \mathrm{O}$ ) was also observed in some conditions. Silanization of the samples was characterized by a clear increase in the Ti-O-Si signal. This increase was higher for samples silanized with BPCTS than with APTES. Subsequent polymerization and peptide attachment reduced the intensity of this signal while increasing the contribution of the carbonyl (CO) peak.

\subsection{Peptide Grafting Polymer}

Table 6. Features of the peptide-functionalized surfaces

\begin{tabular}{lcccc}
\hline Sample & $\mathbf{M}_{\mathbf{n b}}{ }^{\mathbf{a}}$ & $\begin{array}{c}\text { Thickness Increase }\left(\mathbf{h}-\mathbf{h}_{\mathbf{b}}\right)^{\mathbf{b}} \\
(\mathbf{n m})\end{array}$ & $\begin{array}{c}\text { Graft Density } \\
\left(\mathbf{c h a i n} / \mathbf{n m}^{\mathbf{c}}\right)\end{array}$ & $\begin{array}{c}\text { Mass of peptides } \\
\mathbf{W}_{\mathbf{p}}^{\mathbf{d}}\left(\boldsymbol{\mu g} / \mathbf{c m}^{\mathbf{2}}\right)\end{array}$ \\
\hline Ti_AI_Lf & & $7.9 \pm 1.8$ & & $0.9 \pm 0.2$ \\
Ti_ACoI_Lf & 24800 & $12.1 \pm 2.2$ & 0.7 & $1.6 \pm 0.2$ \\
Ti_BCoI_Lf & 22500 & $12.0 \pm 4.8$ & 0.8 & $1.3 \pm 0.1$ \\
\hline
\end{tabular}

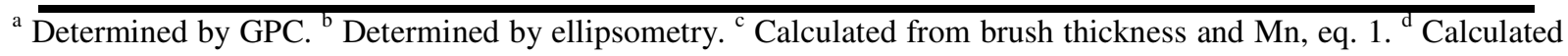
by eq. 4 .

The amount (density) of peptide attached on the surfaces was calculated from the increase in thickness of samples after peptide conjugation (Table 6), being $0.9 \mu \mathrm{g} / \mathrm{cm}^{2}$ for Ti_AI_Lf, $1.6 \mu \mathrm{g} / \mathrm{cm}^{2}$ for Ti_ACoI_Lf and $1.3 \mu \mathrm{g} / \mathrm{cm}^{2}$ for Ti_BCoI_Lf.

\subsection{Cell cytotoxicity assay}

The indirect cytotoxicity of titanium control and samples with the peptide conjugated towards HFFs was studied for 1 day of incubation in different concentration of cell culture extracts (Figure 4). Notably, treated samples did not show significant changes in cell toxicity compared with control titanium (Ti), even in the most concentrated conditions (non diluted medium, complete). All evaluated surfaces showed less than $20 \%$ reduction in cell viability for all the extract concentrations studied. 


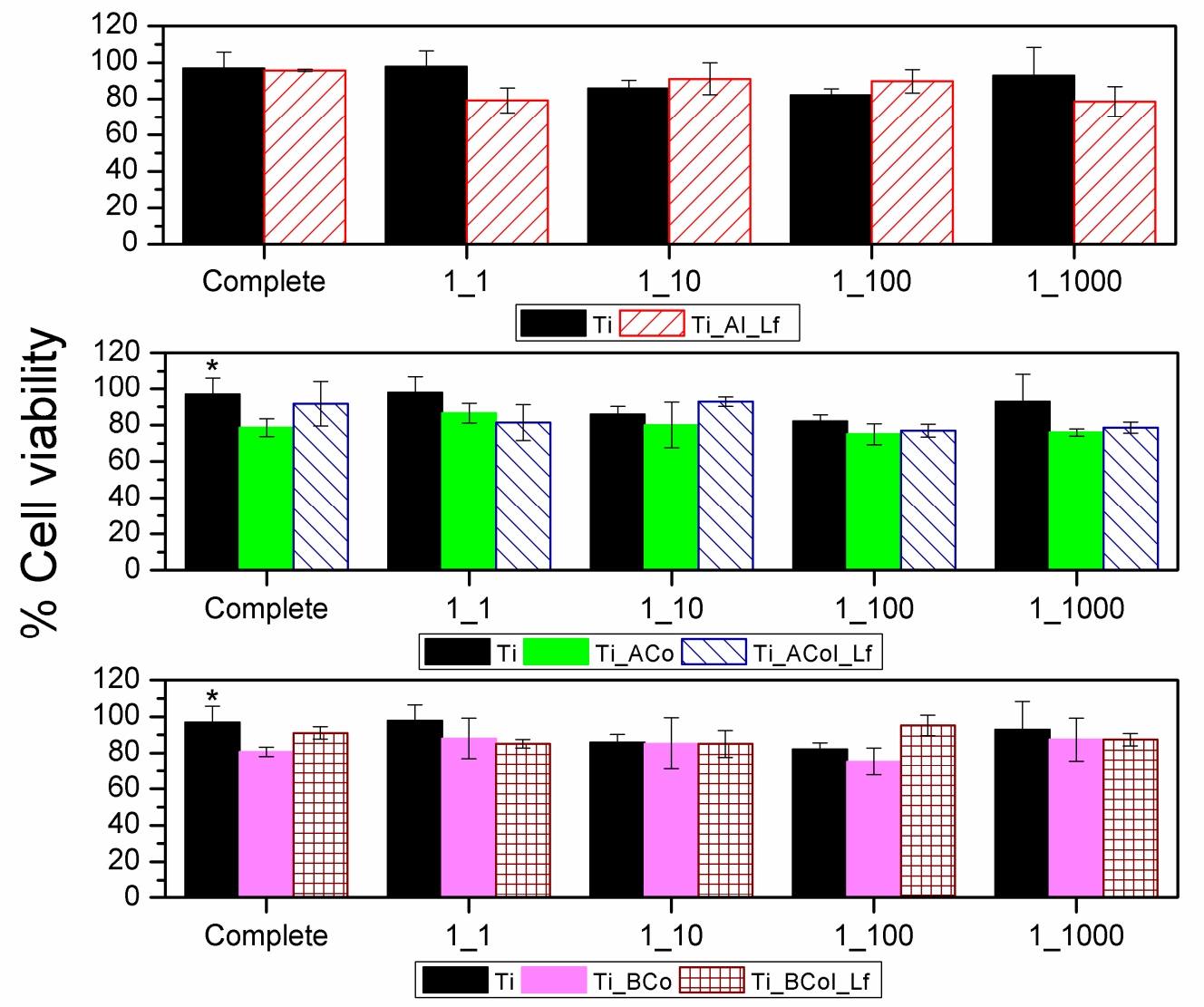

Figure 4. Cytotoxicity of HFFs onto titanium surfaces after 1 day of incubation. Asterisk $\left(^{*}\right)$ indicates statistically significant differences with Ti.

\subsection{Cell proliferation assay}

The proliferation of HFFs on biofunctionalized and control samples was studied after $4 \mathrm{~h}, 1,3$ and 7 days of incubation (Figure 5). Cell proliferation was slightly lower on samples coated with polymer brushes ( $\mathrm{Ti} \_\mathrm{ACo}$ and $\mathrm{Ti}$ _BCo) compared to control titanium. However, after attachment of the hLf1-11 peptide, no significant differences in cell proliferation were observed between the biofunctionalized samples and the controls. Thus, the three strategies of functionalization showed low values of cell toxicity. 

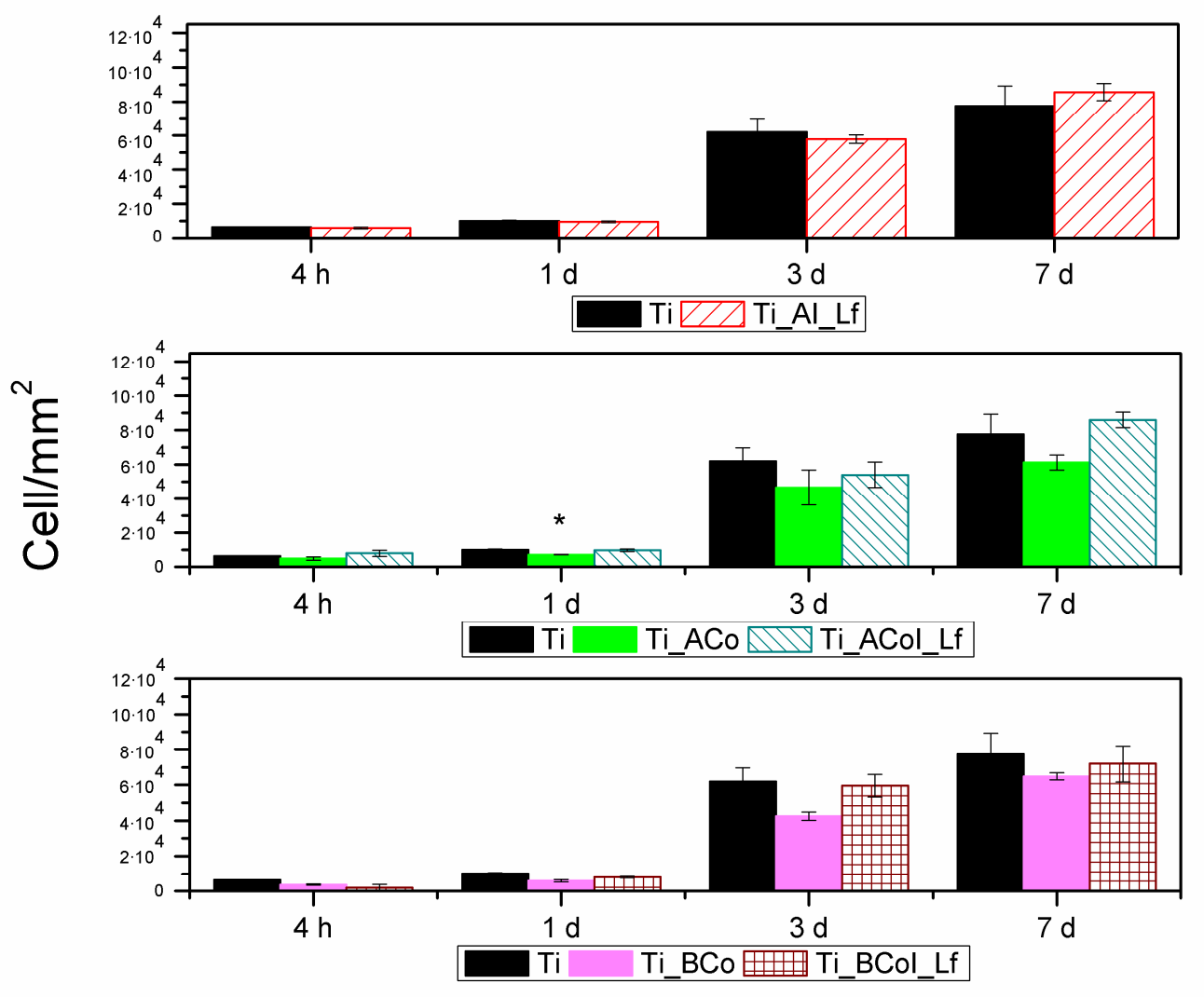

Figure 5. Proliferation of HFFs onto titanium surfaces after 4 h, 1 day, 3 days and 7 days of incubation. Proliferation rates were measured by an LDH assay. Asterisk $\left({ }^{*}\right)$ indicates statistically significant differences with control titanium.

\subsection{Bacterial adhesion on titanium surfaces assay}

Table 7. Percentage of inhibition of bacterial adhesion compared to control titanium (in \%).

\begin{tabular}{lll|ll} 
& \multicolumn{2}{c|}{ Before sonication } & \multicolumn{2}{c}{ After 2 h of sonication } \\
\cline { 2 - 5 } & S.sanguinis & L.salivarius & S.sanguinis & L.salivarius \\
\hline T_AI_Lf & $42.6 \pm 3.4$ & $38.4 \pm 8.3$ & $30.4 \pm 14.9$ & $15.7 \pm 3.6$ \\
T_ACoI_Lf & $60.6 \pm 6.2$ & $55.7 \pm 1.1$ & $28.3 \pm 17.4$ & $15.7 \pm 7.5$ \\
T_BCoI_Lf & $71.9 \pm 1.9$ & $66.2 \pm 7.2$ & $44.8 \pm 12.4$ & $32.9 \pm 4.0$ \\
\hline
\end{tabular}

Results of bacterial adhesion assays for S. sanguinis and L. salivarius after $2 \mathrm{~h}$ incubation on the biofunctionalized samples and their controls are shown in Figure 6. Overall, the immobilization of hLf1-11 peptide on titanium samples significantly inhibited the adhesion of both $S$. sanguinis and L. salivarius to titanium (Table 7). In particular, the highest antibacterial effect was observed when the peptide was attached to polymer brushes (Ti_ACoI_Lf and Ti_BCoI_Lf). 
After $2 \mathrm{~h}$ of sonication, the antibacterial effect observed on titanium was reduced for all strategies. However, the antibacterial properties of the other biofunctionalized samples (strategies 2 and 3) were retained to some extent, showing significant lower values of bacterial adhesion compared to control samples.
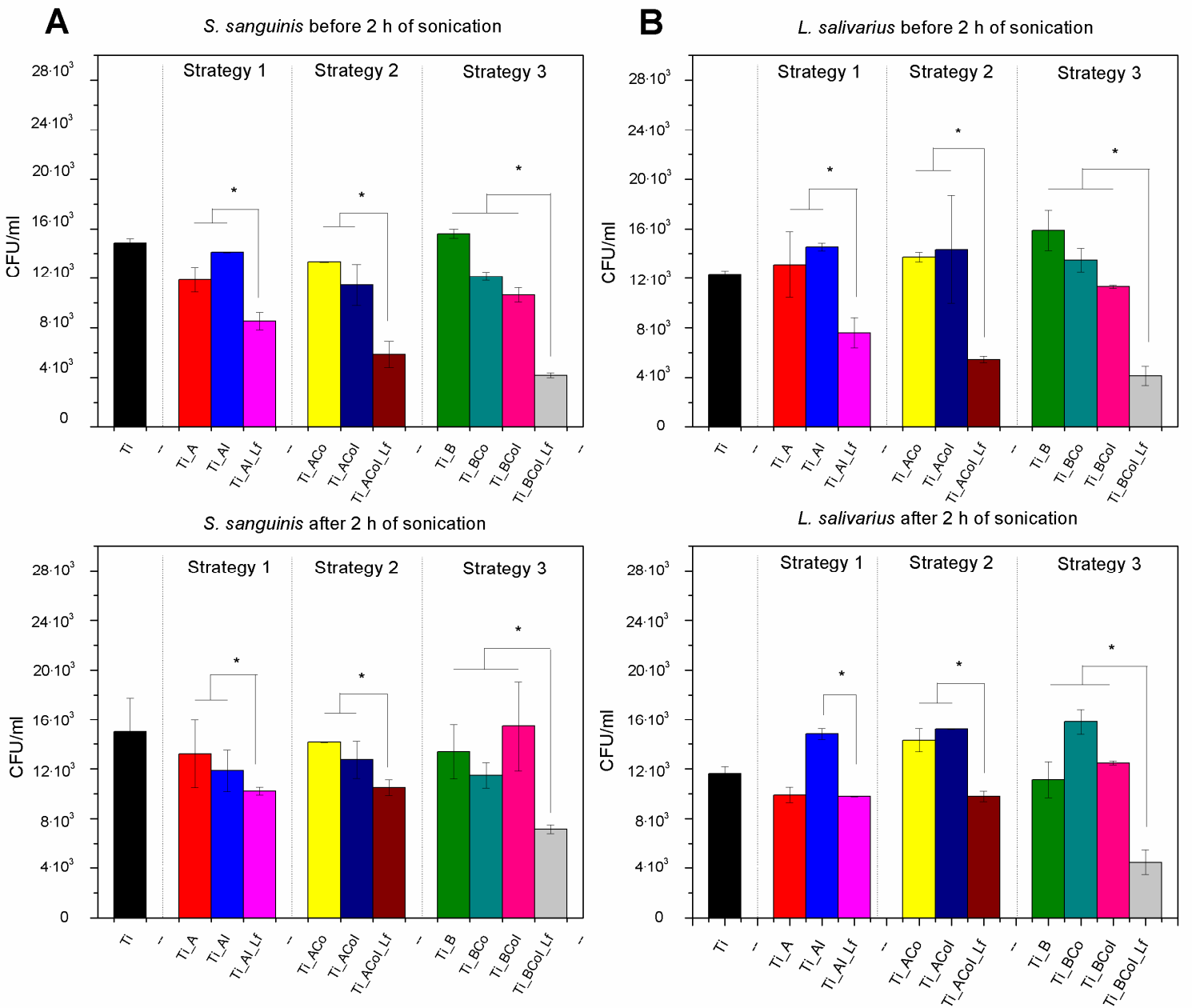

Figure 6. Bacterial adhesion of S. sanguinis (A) and L. salivarius (B) onto titanium samples after $2 \mathrm{~h}$ of incubation at $37^{\circ} \mathrm{C}$. Significant differences are indicated with an “*”. $(\mathrm{P}<0.05)$ 


\subsection{Viability of microorganisms on modified samples}
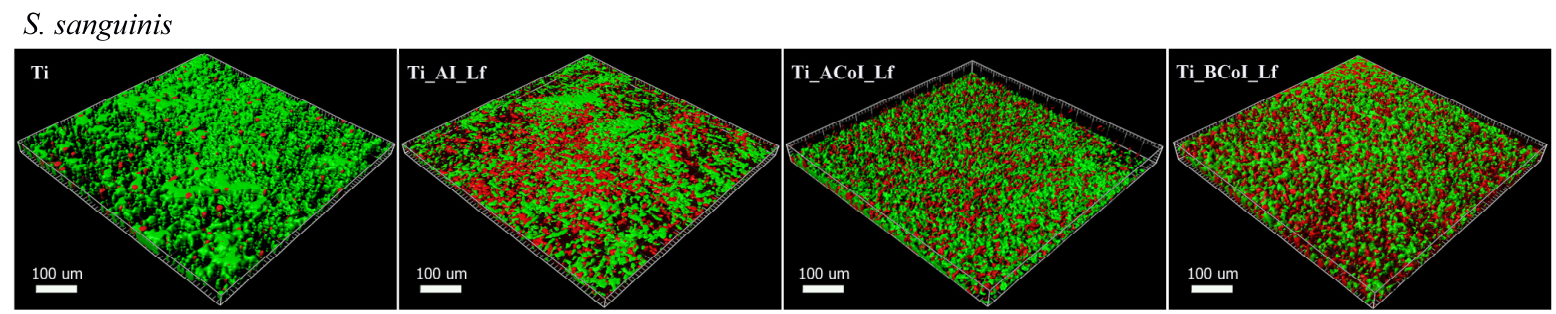

L. salivarius
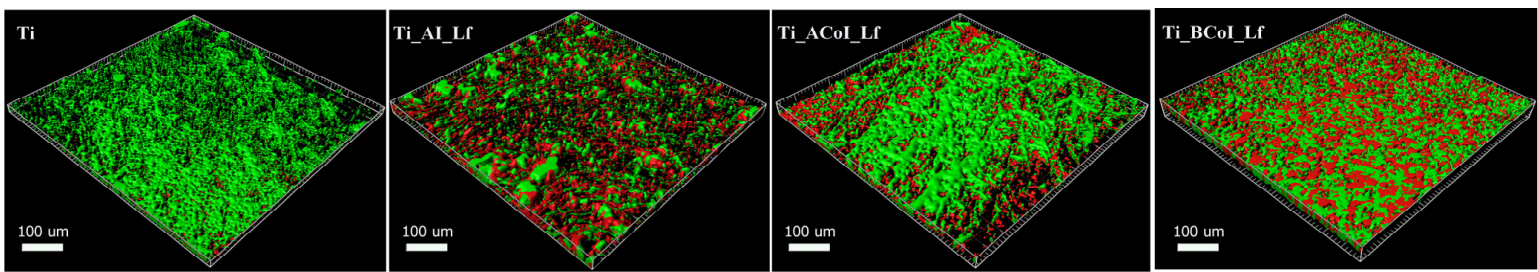

Figure 7. Live/dead staining of S. sanguinis and L. salivarius after $4 \mathrm{~h}$ incubation at $37^{\circ} \mathrm{C}$.

Table 8. Ratio of dead bacteria vs adherent bacteria [red cells/(red cells + green cells)]. Statistically significant differences versus Ti are indicated with an “a”,, versus Ti_AI_Lf with an "b””. ( $\mathrm{P}<0.05)$

\begin{tabular}{lll}
\hline & S.sanguinis & L.salivarius \\
\hline Ti & $0.03^{\mathrm{b}} \pm 0.02$ & $0.002^{\mathrm{b}} \pm 0.002$ \\
Ti_AI_Lf & $0.3^{\mathrm{a}} \pm 0.06$ & $0.3^{\mathrm{a}} \pm 0.05$ \\
Ti_ACoI_Lf & $0.4^{\mathrm{a}, \mathrm{b}} \pm 0.1$ & $0.6^{\mathrm{a}, \mathrm{b}} \pm 0.04$ \\
Ti_BCoI_Lf & $0.5^{\mathrm{a}, \mathrm{b}} \pm 0.07$ & $0.5^{\mathrm{a}, \mathrm{b}} \pm 0.1$ \\
\hline
\end{tabular}

To further confirm the antibacterial properties of the biofunctionalized samples, a LIVE/DEAD backlight bacterial viability assay was performed. As shown in Figure 7 a large number of viable bacterial cells (green dots) were found on control samples. In contrast, the presence of the lactoferrin peptide clearly reduced the number of viable bacteria on the surfaces for both bacterial strains. As previously observed, polymer brush based treatment method displayed the highest antibacterial effect against $S$. sanguinis and L.salivarius, as shown by the calculated ratios of bacterial death (Table 8). 


\subsection{Evaluation of biofilm formation on titanium surfaces assay}

A

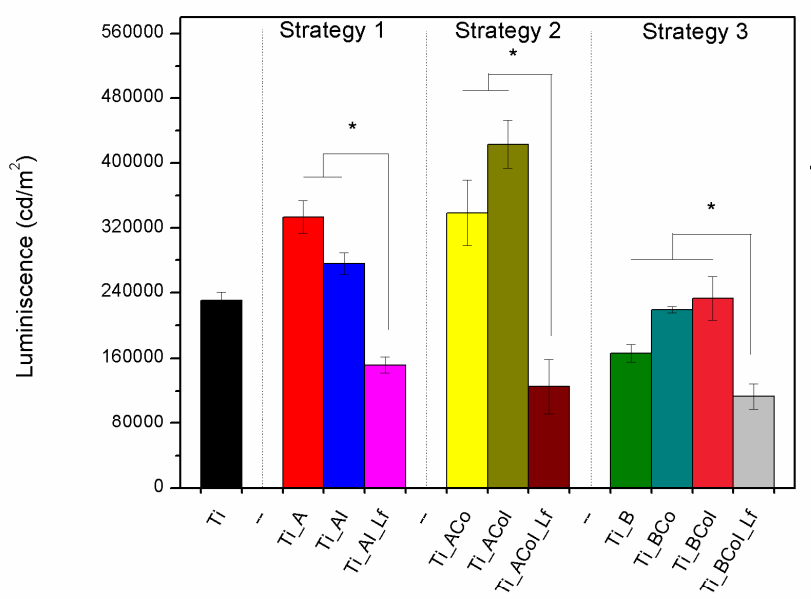

S. sanguinis after $2 \mathrm{~h}$ of sonication

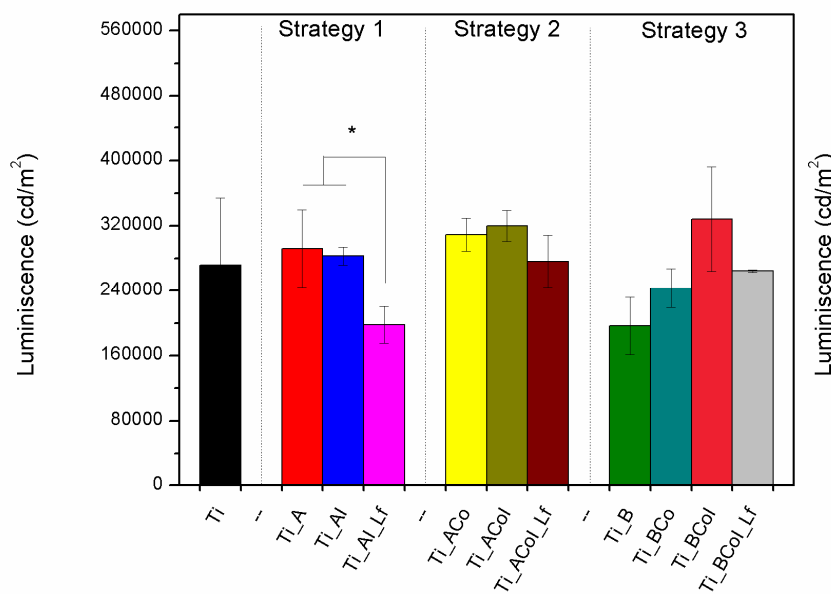

B

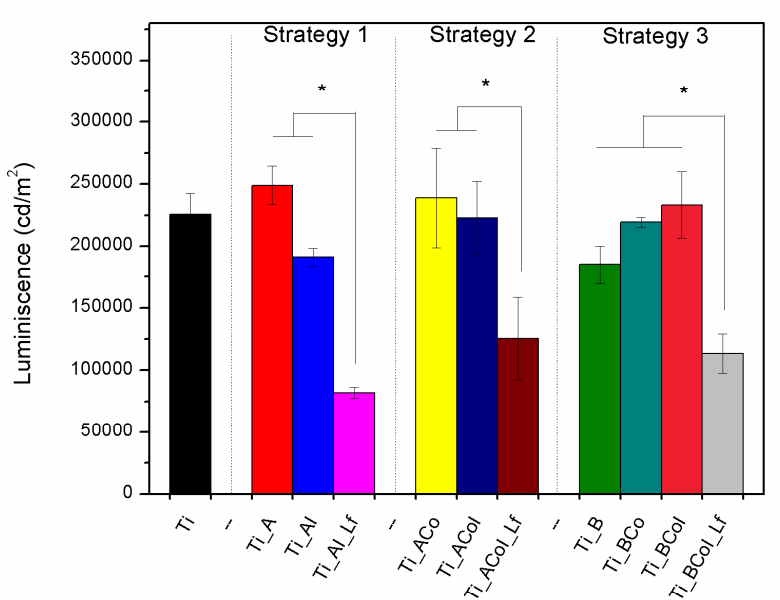

L. salivarius after $2 \mathrm{~h}$ of sonication

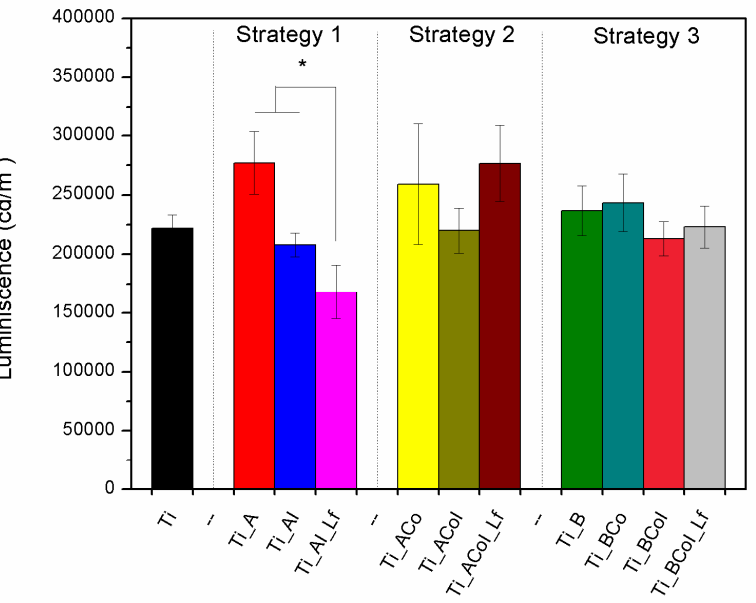

Figure 8. Bacterial biofilm formation of $S$. sanguinis (A) and L. salivarius (B) onto titanium samples after $24 \mathrm{~h}$ incubation at $37^{\circ} \mathrm{C}$. Statistically significant differences are indicated with an “*”. ( $\left.\mathrm{P}<0.05\right)$

Table 9. Percentage of inhibition of biofilm formation compared to control Titanium (in \%).

\begin{tabular}{lcc|cc}
\cline { 2 - 5 } & \multicolumn{2}{c|}{ Before sonication } & \multicolumn{2}{c}{ After 2 h of sonication } \\
\cline { 2 - 5 } & S.sanguinis & L.salivarius & S.sanguinis & L.salivarius \\
\hline T_AI_Lf & $34.2 \pm 1.4$ & $61.6 \pm 2.0$ & $24.9 \pm 14.4$ & $24.3 \pm 6.3$ \\
T_ACOI_Lf & $47.2 \pm 13.9$ & $47.3 \pm 14.0$ & $14.1 \pm 6.8$ & $24.5 \pm 8.0$ \\
T_BCoI_Lf & $50.6 \pm 8.9$ & $52.3 \pm 6.6$ & $22.2 \pm 3.03$ & $9.34 \pm 1.4$ \\
\hline
\end{tabular}

Samples coated with hLf1-11 peptide showed a drastic reduction in the formation of biofilm after $2 \mathrm{~h}$ of incubation with both bacterial strains (Figures 8 and Table 9). However, after $2 \mathrm{~h}$ sonication, its effectiveness was almost negligible when strategies 2 and 3 were applied. In contrast, in comparison to these treatments, the antibacterial effect on Ti_AI_Lf samples was maintained after the sonication treatment. On the whole, $S$. sanguinis and L. salivarius showed a similar trend on all samples. 


\section{DISCUSSION}

In this study, we compared two different methods to immobilize the AMP hLf1-11 onto titanium surfaces: silanization with APTES and ATRP with a DMA-APMA copolymer to generate polymer brushes (Figure 3). One of the main hypotheses of this work was that the use of polymer brushes, which contain multiple reactive points for peptide attachment, could increase the number of hLf1-11 molecules onto titanium, thereby improving the antibacterial activity of the surfaces compared to simple silanization methods. To prove this assumption, we have characterized the physicochemical properties of the biofunctionalized surfaces and tested their ability to inhibit bacterial adhesion and reduce early stages of biofilm formation in vitro.

Human lactoferrin (hLf) is a multifunctional protein, consisting of a polypeptide chain of 692 amino acids, that displays a diversity of biological functions, including antiviral, antifungal and antibacterial properties ${ }^{44,45}$. Noteworthy, the synthetic peptide hLf1-11 (derived from the 1-11 sequence at the $\mathrm{N}$-terminus of $\mathrm{hLf}$ ) was able to retain the antibacterial activity of the whole protein, mostly through binding and disturbing the membrane of a broad range of bacteria ${ }^{46}$. In a recent study, we demonstrated that this peptide can be anchored to titanium surfaces and exhibit potent antibacterial effects ${ }^{8}$.

Titanium was used as model substrate because it is the material of choice for the majority of implants used for dental applications ${ }^{47,48}$. However, due to the relatively chemical inertness of titanium oxide layers, its surface modification often requires the use of activation methods ${ }^{49,50,51}$. In this work, oxygen plasma was selected to clean and activate the surfaces prior to their functionalization. Plasma activation has demonstrated to be very efficient in removing hydrophobic contaminants and increasing the number of hydroxyl groups available on the surface, which are required for an efficient silanization ${ }^{8,23,38}$. Moreover, this activation method does not modify the topography (i.e. roughness) of the surfaces, as observed with other methods such as acidic $^{51}$ or alkaline ${ }^{52,53}$ etchings.

After surface activation, titanium samples were modified either with APTES or BPTCS (Figure 3). Silanization with APTES was carried out following well-reported protocols ${ }^{8,54,55}$. In strategy 1, terminal amino groups on the silanes were conveniently iodo-acylated to ensure the chemoselective reaction of these electrophilic $-\mathrm{CH}_{2}$-I centers with nucleophilic thiol groups of hLf1-11, without affecting the residues present in the peptide's active sequence. Moreover, the hLf1-11 peptide was designed with a spacer unit of three Ahx to provide an adequate separation of the peptide sequence from the coated material, and thus ensure an optimal accessibility and presentation of the AMP on the surfaces ${ }^{8,56,57}$. As a matter of fact, we demonstrated in previous studies that peptides bearing spacer molecules too short in length failed to reproduce the expected biological activity on the coated surfaces ${ }^{56,57}$. Alternatively, silanization with APTES (strategy 2) or BPTCS (strategy 3) was followed by ATRP polymerization to generate copolymer brushes on the surface. These two strategies differ in the reactive group of each silane. The amino group of APTES cannot be used to initiate the ATRP, and, therefore, an extra step (i.e. 
reaction with 2-chloropropionyl chloride) is necessary to generate a reactive ATRP initiator onto the surface. On the contrary, BPTCS contains as a terminal group bromide $(\mathrm{Br})$, which already serves as the initiating specie. Afterwards, radicals are generated through the dormant species periodically reacting with the transition metal complexes in their lower oxidation state. In this case (strategies 2 and 3), the hLf1-11 peptide was used without the spacer unit (GRRRRSVQWAC) because the structure of the brushes already provides a good separation of the peptides from the surfaces.

\subsection{Physicochemical characterization of the surfaces}

Wettability and SFE are key parameters determining the adsorption of biomolecules onto surfaces and therefore controlling the adhesion of cells and bacteria ${ }^{58,59}$. Moreover, changes in the wettability of the samples can be used to monitor the process of functionalization (Table 1). Thus, as expected, silanization was characterized by a significant increase in the water contact angle due to the hydrophobic nature of the silane molecules. The difference in contact angle values between these two silanes $\left(\mathrm{Ti} \_\mathrm{A}=74.0^{\circ}\right.$; Ti_B $=94.8^{\circ}$ ) can be explained by their distinct chemical properties: APTES contains as functional group a primary amine, positively charged at neutral/physiological $\mathrm{pH}$ and thus hydrophilic; whereas BPTCS contains instead a bromosubstituted isopropyl group, which is much more hydrophobic. Conversely, the copolymerization of DMA-APMA augmented the hydrophilic character of the samples, owing to the high number of amides and amine groups present in the brushes. For all three strategies, the anchoring of the antibacterial peptide was accompanied with a significant variation in the water CA towards intermediate values of hydrophilicity, consistent with the amphipathic character of the peptides. Both CA and SFE values for all three surfaces were similar, suggesting that a similar peptide coverage is obtained in the outer layer of the polymers.

Topographical features (i.e. roughness) on material surfaces are also crucial in cell and tissue responses to biomaterials. Indeed, surface roughness has shown to alter fibroblast proliferation on aluminiun, titanium and titanium alloys substrates ${ }^{60-62}$, and strongly influence bacterial attachment to nitinol, titanium and glass surfaces ${ }^{63-66}$. Overall, the three functionalization strategies displayed the same value of $R_{a}(\sim 30 \mathrm{~nm}$; Table 2$)$, slightly increasing the original $R_{a}$ of control samples ( $25 \mathrm{~nm}$; Table 2). However, this difference in roughness is too small to significantly affect either HFFs proliferation or bacterial attachment. Additionally, the coating methods increased both $R_{\mathrm{sk}}$ and $\mathrm{R}_{\mathrm{ku}}$ parameters of the surfaces. These two parameters describe the asymmetry and peakedness of the roughness profiles, respectively. Since $R_{\text {sk }}>0$ and $R_{k u}>3$ describe the presence of unordered relatively high peaks, and absence of deep valleys ${ }^{34}$. Our results are consistent with the deposition of polymer layers and peptide attachments smoothing topographical valleys at the nanometer level. This assumption was corroborated by examining the thickness of the coatings by ellipsometry (Table 3).

In all cases, an increase of approximately 7-15 nm of thickness was observed after peptide attachment, which indicates a successful anchoring of hLf1-11 onto titanium. Comparing the 
different methods, it is evident that polymer brush based method provided much higher coating thicknesses than mere silanization with APTES. It is plausible that higher layer thickness could be translated in a larger number of hLf1-11 molecules on the surface; other complimentary techniques, however, should be used to ascertain that. The $20 \mathrm{~nm}$ rise in thickness for both copolymer brush layers (strategy 1 and 2) can suggest in part an interdiffusion of the peptide into the coating and an increase of the peptide density on the surface as expected.

Moreover, the mass of the peptide $\left(\mathrm{W}_{\mathrm{p}}\right)$ was calculated from the thickness increase of the polymer layer with a result of $1.7 \mu \mathrm{g} / \mathrm{cm}^{2}$ for Ti_ACoI_Lf and $1.3 \mu \mathrm{g} / \mathrm{cm}^{2}$ for Ti_BCoI_Lf (Table 6). Although the peptide mass on Ti_ACoI_Lf samples presented higher values than that on Ti_BCoI_Lf samples, not significant differences between both strategies were measured, which suggested that both are able to attach a similar amount of peptide onto titanium surface. Furthermore, Wp was evaluated for strategy $1\left(0.9 \mu \mathrm{g} / \mathrm{cm}^{2}\right.$ for Ti_AI_Lf $)$. As we expected, the amount of peptide immobilized onto the surface by silanization is lower in comparison with ATRP.

The elemental surface composition of the treated substrates was analyzed by means of XPS (Table 4 and Table 5). Silanization was characterized by the presence of silicon ( $\mathrm{Si} 2 \mathrm{p}$ signal, Table 4) and the Ti-O-Si peak (Table 5) on Ti_A and Ti_B samples. On the basis of Si/Ti ratios, silanization with BPTCS appeared to yield slightly higher silane coverage than the use of APTES. These differences, however, were not corroborated by ellipsometry measurements and therefore might not be significant. ATRP could be also monitored by characteristic amide group signals (Tables 5). Finally, peptide attachment on the surfaces was determined by a clear increase in the percentage of carbon and nitrogen levels and a decrease in the detectable signals of titanium oxide, in comparison with control samples. In particular, an enhanced $\mathrm{N}$ 1s signal is attributed to amide groups of the peptide sequence ${ }^{67}$, as confirmed by $\mathrm{C} 1 \mathrm{~s}$ and $\mathrm{O} 1 \mathrm{~s}$ deconvolutions (Tables 5).. However, the fact that APTES and DMPA-APMA copolymers also contain carbon and nitrogen in their structures, does not allow a direct comparison within the strategies to measure the efficiency in peptide coupling. In contrast, the presence of sulfur is an unequivocal indicator of peptide attachment. Therefore, S/Ti ratios were calculated to compare the efficiency of the distinct coatings methods. According to these ratios, the amount of peptide attached on the surfaces via silanization with APTES was lower than the values obtained via the ATRP methodology. Moreover, the extent of peptide attachment with polymer brushes seemed to be relatively independent from the initiation used (APTES or BPTCS). As we previously commented, it is reasonable to assume that the enhancement in peptide attachment is owing to the high amount of reactive groups present in the brush chain. 


\subsection{Biological characterization of the surfaces}

The adhesion and proliferation of HFFs on the biofunctionalized surfaces was studied, to discard any possible unspecific toxicity of the coating systems (Figure 4 and Figure 5). Noteworthy, as we already reported ${ }^{8}$ the hLf1-11 peptide did not show any direct or indirect cytotoxic effects on HFFs, as evidenced by rates of proliferation similar to those observed on control titanium for up to 7 days of incubation. Although some reduction in cell viability was observed for the samples coated with the copolymer brushes, such reduction was lower than $20 \%$ compared to control Ti. According to the International Organization for Standarization (ISO 10993-6:2007), reductions in cell viability below this value are not considered cytotoxic effects. Thus both the hLf1-11 peptide and the coating methods used in this study show low cytotoxicity against HFFs ${ }^{8,38,40}$.

Once the biofunctionalized surfaces were characterized, we turned our attention to whether the higher amount of peptide immobilized on the polymer brushes improved the antibacterial properties of the treated surfaces. We investigated bacterial adhesion and early stages of biofilm formation on hLf1-11-coated samples with two oral bacterial strains: S. sanguinis and $L$. salivarius. These two strains were chosen because they are actively implicated in oral biofilms. S. sanguinis is a primary colonizer of biomaterial surfaces in the oral cavity, and forms linkages between the surfaces and newly adhering and growing bacteria. L. salivarius interacts with other secondary colonizers and their by-products are essential for biofilm formation and maintenance ${ }^{68,69}$. Both quantitative and qualitative assays demonstrated that the attachment of hLf1-11 reduced the adhesion of bacteria on titanium surfaces (Figure 6) and that this peptide displayed bactericidal effects on the surface (Figure 7 and Table 9). Interestingly, titanium samples modified by ATRP method (strategies 2 and 3) showed reduced numbers of bacterial adhesion and bacterial viability for both bacterial strains compared to samples silanized with APTES (strategy 1) (Figures 6 and 7). Moreover, ATRP strategies have a higher inhibition in bacterial adhesion in comparison with silanization process (Table 7). The better antibacterial adhesion shown by ATRP based method can be correlated to a combination of high peptide density and non-fouling propeties of the PDMA segment (Table 4).

Finally, the effect of the antibacterial surfaces on biofilm formation was also evaluated (Figure 8 and Table 9). It should be highlighted that samples functionalized with hLf1-11 inhibited early stages of biofilm formation for both oral strains. Interestingly, once the percentage of inhibition was studied, the effect in S.sanguinis is correlated with the results obtained in bacterial adhesion. Each strain, however, has a distinct response to the antimicrobial surfaces, as it has been studied in previous studies ${ }^{8,70}$. Whereas biofilm formation of S.sanguinis was clearly higher inhibited by ATRP-coatings, no significant reduction in bacterial inhibition was observed for L.salivarius among all three strategies. Thus, these results revealed the possibility that the DMA-co-APMA has accumulated water at the polymer-silicon interface and subsequent detachment of the coating with the peptide. 
Concurrently, the stability of the coatings was analyzed. After $2 \mathrm{~h}$ of ultrasonication in PBS, the antibacterial properties of the functionalized surfaces (inhibition of bacterial adhesion and biofilm growth) decreased, regardless of the strategy (Figures 6 and 8). These results indicate partial loss of the hLf11-11 peptide on the surfaces, which might be due to hydrolysis of the siloxane layers and/or the polymer brushes (polymer chains were attached through a silane layer). This assumption is supported by the decrease in silane and brush thickness observed by ellipsometry (Table 3). Moreover, ultrasonication may also remove peptide non-covalently bound (i.e. physically adsorbed). The susceptibility of the silanes as well as the polymer chains to hydrolysis by ultrasonication was also observed by changes in water CA values (Table 1). In this regard, BPTCS seemed to be more sensitive to hydrolysis than APTES. Another plausible explanation could be that a large extent of BPTCS was bound to the surface via non-covalent interactions, resulting in higher loss of silane during sonication compared to surfaces silanized with APTES. Interestingly, and in contrast to the use of BPTCS, for strategies 1 and 2 (APTESmediated) there was no change in CA on the surfaces after the stability treatment, suggesting that despite some extent of peptide detachment, the resulting surfaces may still present a layer of peptide similar to the samples prior to the stability treatment. Thus, ATRP using APTES would be a preferred method than using BPTCS for future applications. Furthermore, incubation of both silane layers in PBS for an extra period of $24 \mathrm{~h}$ only resulted in a minor decrease of CA (see supplementary information Table 1), confirming the stability of the coating for at least the early stages of biofilm formation.

Thus, it should be taken into account that mechanical or thermal challenges may reduce the quantity of peptide attached to the surface and compromise the antibacterial activity. Therefore, the use of such treatments is discouraged for these coatings. However, it is remarkable that even after an aggressive stability treatment, the capacity of the coatings to reduce the adhesion of both S. sanguinis and L. salivarius was maintained (Figure 6). In particular, APTES-silanized samples were also able to display some extent of inhibition of biofilm formation (Figure 8) after the ultrasonication.

Overall, in this work we have shown that the immobilization of hLf1-11 to titanium by either silanization with APTES or ATRP-mediated methods significantly reduced bacterial adhesion and biofilm formation of $S$. sanguinis and $L$. salivarius. The use of copolymer (DMAco-APMA) brushes efficiently increased the number of peptides attached to the surfaces compared to simple silanization. Such increase in peptide attachment was translated into an increase in the inhibition of bacterial adhesion and a reduction of bacterial viability and biofilm formation. Thus, the use of polymer brush based approach is a potential alternative to classical methods of biomolecule immobilization and may lead to coatings with increased antibacterial properties. The stability of these coatings towards sterilization and mechanical challenges requires further investigation. 


\section{CONCLUSION}

Our study has characterized and compared two different processes in order to immobilize the hLf1-11 peptide onto titanium surfaces. The biofunctionalized surfaces were characterized in detail by physicochemical and biological methods. XPS analysis confirmed the greater amount of peptide attached onto the surfaces functionalized via ATRP than those functionalized via silane. No cytotoxic effects were observed against human fibroblasts, indicating the excellent biocompatibility of the samples. Both strategies promoted a significant decrease in bacteria adhesion and early stages of biofilm formation of S. sanguinis and L. salivarius, with a higher decrease measured for surfaces modified by polymer brush based methods compared to direct silanization. This effect was attributed to the higher capacity of the polymer brushes to immobilize peptide on the surfaces and the non-fouling propeties of the PDMA segment. Further investigation may include antibacterial assays using complete oral biofilm to test the antibacterial properties of these coatings in a more realistic dental model.

\section{ACKNOWLEDGMENTS}

This study was supported by the Ministry of Science and Innovation (MICINN) and the Ministry of Economy and Competitiveness (MINECO) of the Spanish Government (Projects: MAT200912547, MAT2012-30706 co-funded by the European Union through European Regional Development Funds). C.M.-M. thanks the support of the Secretary for Universities and Research of the Ministry of Economy and Knowledge of the Government of Catalonia (2011-BP-B-00042) and the People Programme (Marie Curie Actions) of the European Union's Seventh Framework Programme (FP7-PEOPLE-2012-CIG, REA grant agreement $n^{\circ}$ 321985).

The infrastructure facility at the Centre for Blood Research is supported by the Canada Foundation for Innovation (CFI), the British Columbia Knowledge Development Fund (BCKDF). JNK acknowledges Career Investigator Scholar award from Michael Smith Foundation for Health Research (MSFHR). 


\section{REFERENCES}

(1) Pye, A. D.; Lockhart, D. E. A.; Dawson, M. P.; Murray, C. A.; Smith, A. J. J. Hosp. Infect. 2009, 72, $104-110$.

(2) Foster, J. S.; Kolenbrander, P. E. Appl. Environ. Microbiol. 2004, 70, 4340-4348.

(3) Kolenbrander, P. E.; Andersen, R. N.; Blehert, D. S.; Egland, P. G.; Foster, J. S.; Palmer, R. J., Jr. Microbiol. Mol. Biol. Rev. MMBR 2002, 66, 486-505.

(4) Okahashi, N.; Nakata, M.; Terao, Y.; Isoda, R.; Sakurai, A.; Sumitomo, T.; Yamaguchi, M.; Kimura, R. K.; Oiki, E.; Kawabata, S.; Ooshima, T. Microb. Pathog. 2011, 50, 148-154.

(5) Black, C.; Allan, I.; Ford, S. K.; Wilson, M.; McNab, R. Arch. Oral Biol. 2004, 49, 295-304.

(6) Almståhl, A.; Carlén, A.; Eliasson, L.; Lingström, P. Arch. Oral Biol. 2010, 55, 255-259.

(7) Yang, R.; Argimon, S.; Li, Y.; Gu, H.; Zhou, X.; Caufield, P. W. J. Microbiol. Methods 2010, 82, $163-169$.

(8) Godoy-Gallardo, M.; Mas-Moruno, C.; Fernández-Calderón, M. C.; Pérez-Giraldo, C.; Manero, J. M.; Albericio, F.; Gil, F. J.; Rodríguez, D. Acta Biomater. 2014, 10, 3522-3534.

(9) Costa, F.; Carvalho, I. F.; Montelaro, R. C.; Gomes, P.; Martins, M. C. L. Acta Biomater. 2011, 7, $1431-1440$.

(10) Silva, T.; Adão, R.; Nazmi, K.; Bolscher, J. G. M.; Funari, S. S.; Uhríková, D.; Bastos, M. Biochim. Biophys. Acta 2013, 1828, 1329-1339.

(11) Brogden, K. A. Nat. Rev. Microbiol. 2005, 3, 238-250.

(12) Haukland, H. H.; Ulvatne, H.; Sandvik, K.; Vorland, L. H. FEBS Lett. 2001, 508, 389-393.

(13) Gifford, J. L.; Hunter, H. N.; Vogel, H. J. Cell. Mol. Life Sci. CMLS 2005, 62, 2588-2598.

(14) Berlutti, F.; Pantanella, F.; Natalizi, T.; Frioni, A.; Paesano, R.; Polimeni, A.; Valenti, P. Molecules 2011, 16, 6992-7018.

(15) Soukka, T.; Tenovuo, J.; Lenander-Lumikari, M. FEMS Microbiol. Lett. 1992, 69, 223-228.

(16) Weinberg, G. A. Antimicrob. Agents Chemother. 1994, 38, 997-1003.

(17) Bellamy, W.; Takase, M.; Wakabayashi, H.; Kawase, K.; Tomita, M. J. Appl. Bacteriol. 1992, 73, 472-479.

(18) Yen, C.-C.; Shen, C.-J.; Hsu, W.-H.; Chang, Y.-H.; Lin, H.-T.; Chen, H.-L.; Chen, C.-M. BioMetals 2011, 24 , 585-594.

(19) González-Chávez, S. A.; Arévalo-Gallegos, S.; Rascón-Cruz, Q. Int. J. Antimicrob. Agents 2009, 33, 301.e1e301.e8.

(20) Ulvatne, H.; Haukland, H. H.; Olsvik, Ø.; Vorland, L. H. FEBS Lett. 2001, 492, 62-65.

(21) Vorland, L. H.; Ulvatne, H.; Rekdal, O.; Svendsen, J. S. Scand. J. Infect. Dis. 1999, 31, 467-473.

(22) Brouwer, C. P. J. M.; Rahman, M.; Welling, M. M. Peptides 2011, 32, 1953-1963.

(23) Chen, X.; Sevilla, P.; Aparicio, C. Colloids Surf. B Biointerfaces 2013, 107, 189-197.

(24) Li, X.; Li, P.; Saravanan, R.; Basu, A.; Mishra, B.; Lim, S. H.; Su, X.; Tambyah, P. A.; Leong, S. S. J. Acta Biomater. 2014, 10, 258-266.

(25) Xiao, S. J.; Textor, M.; Spencer, N. D.; Wieland, M.; Keller, B.; Sigrist, H. J. Mater. Sci. Mater. Med. 1997, 8, $867-872$.

(26) Xiao, S.-J.; Textor, M.; Spencer, N. D.; Sigrist, H. Langmuir 1998, 14, 5507-5516.

(27) Dettin, M.; Bagno, A.; Gambaretto, R.; Iucci, G.; Conconi, M. T.; Tuccitto, N.; Menti, A. M.; Grandi, C.; Di Bello, C.; Licciardello, A.; Polzonetti, G. J. Biomed. Mater. Res. A 2009, 90A, 35-45.

(28) De Souza Cândido, E.; e Silva Cardoso, M. H.; Sousa, D. A.; Viana, J. C.; de Oliveira-Júnior, N. G.; Miranda, V.; Franco, O. L. Peptides 2014, 55, 65-78.

(29) Forbes, S.; McBain, A. J.; Felton-Smith, S.; Jowitt, T. A.; Birchenough, H. L.; Dobson, C. B. Biomaterials 2013, 34, 5453-5464.

(30) Hadjesfandiari, N.; Yu, K.; Mei, Y.; Kizhakkedathu, J. N. J. Mater. Chem. B 2014, 2, 4968-4978.

(31) Minko, S. In Polymer Surfaces and Interfaces; Stamm, M., Ed.; Springer Berlin Heidelberg, 2008, $215-234$.

(32) Zhao, B.; Brittain, W. J. Prog. Polym. Sci. 2000, 25, 677-710.

(33) Halperin, A.; Tirrell, M.; Lodge, T. P. In Macromolecules: Synthesis, Order and Advanced Properties; Advances in Polymer Science; Springer Berlin Heidelberg, 1992, 31-71.

(34) Milner, S. T.; Witten, T. A.; Cates, M. E. Macromolecules 1988, 21, 2610-2619.

(35) Edmondson, S.; Osborne, V. L.; Huck, W. T. S. Chem. Soc. Rev. 2004, 33, 14.

(36) Fan, X.; Lin, L.; Messersmith, P. B. Biomacromolecules 2006, 7, 2443-2448.

(37) Fan, X.; Lin, L.; Dalsin, J. L.; Messersmith, P. B. J. Am. Chem. Soc. 2005, 127, 15843-15847.

(38) Gao, G.; Yu, K.; Kindrachuk, J.; Brooks, D. E.; Hancock, R. E. W.; Kizhakkedathu, J. N. Biomacromolecules 2011, 12, 3715-3727.

(39) Ran, J.; Wu, L.; Zhang, Z.; Xu, T. Prog. Polym. Sci. 2014, 39, 124-144. 
(40) Gao, G.; Lange, D.; Hilpert, K.; Kindrachuk, J.; Zou, Y.; Cheng, J. T. J.; Kazemzadeh-Narbat, M.; Yu, K.; Wang, R.; Straus, S. K.; Brooks, D. E.; Chew, B. H.; Hancock, R. E. W.; Kizhakkedathu, J. N. Biomaterials 2011, 32, 3899-3909.

(41) Matyjaszewski, K.; Miller, P. J.; Shukla, N.; Immaraporn, B.; Gelman, A.; Luokala, B. B.; Siclovan, T. M.; Kickelbick, G.; Vallant, T.; Hoffmann, H.; Pakula, T. Macromolecules 1999, 32, 8716-8724.

(42) Peltonen, J.; Järn, M.; Areva, S.; Linden, M.; Rosenholm, J. B. Langmuir 2004, 20, 9428-9431.

(43) Gadelmawla, E. S.; Koura, M. M.; Maksoud, T. M. A.; Elewa, I. M.; Soliman, H. H. J. Mater. Process. Technol. 2002, 123, 133-145.

(44) Arnold, R. R.; Cole, M. F.; McGhee, J. R. Science 1977, 197, 263-265.

(45) Brouwer, C. P. J. M.; Rahman, M.; Welling, M. M. Peptides 2011, 32, 1953-1963.

(46) Jenssen, H.; Hancock, R. E. W. Biochimie 2009, 91, 19-29.

(47) Brunette, D. M. Titanium in Medicine: Material Science, Surface Science, Engineering, Biological Responses, and Medical Applications; Springer, 2001.

(48) McCracken, M. J. Prosthodont. 1999, 8, 40-43.

(49) Wälivaara, B.; Aronsson, B.-O.; Rodahl, M.; Lausmaa, J.; Tengvall, P. Biomaterials 1994, 15, 827-834.

(50) Modes, T.; Scheffel, B.; Metzner, C.; Zywitzki, O.; Reinhold, E. Surf. Coat. Technol. 2005, 200, $306-309$.

(51) Ban, S.; Iwaya, Y.; Kono, H.; Sato, H. Dent. Mater. 2006, 22, 1115-1120.

(52) Kim, H. M.; Miyaji, F.; Kokubo, T.; Nakamura, T. J. Mater. Sci. Mater. Med. 1997, 8, 341-347.

(53) Nishiguchi, S.; Kato, H.; Fujita, H.; Oka, M.; Kim, H.-M.; Kokubo, T.; Nakamura, T. Biomaterials 2001, 22, 2525-2533.

(54) Rodríguez-Cano, A.; Cintas, P.; Fernández-Calderón, M.-C.; Pacha-Olivenza, M.-Á.; Crespo, L.; Saldaña, L.; Vilaboa, N.; González-Martín, M.-L.; Babiano, R. Colloids Surf. B Biointerfaces 2013, 106, 248-257.

(55) Yadav, A. R.; Sriram, R.; Carter, J. A.; Miller, B. L. Mater. Sci. Eng. C 2014, 35, 283-290.

(56) Mas-Moruno, C.; Dorfner, P. M.; Manzenrieder, F.; Neubauer, S.; Reuning, U.; Burgkart, R.; Kessler, H. J. Biomed. Mater. Res. A 2013, 101A, 87-97.

(57) Rechenmacher, F.; Neubauer, S.; Mas-Moruno, C.; Dorfner, P. M.; Polleux, J.; Guasch, J.; Conings, B.; Boyen, H.-G.; Bochen, A.; Sobahi, T. R.; Burgkart, R.; Spatz, J. P.; Fässler, R.; Kessler, H. Chem. - Eur. J. 2013, 19, 9218-9223.

(58) Rupp, F.; Gittens, R. A.; Scheideler, L.; Marmur, A.; Boyan, B. D.; Schwartz, Z.; Geis-Gerstorfer, J. Acta Biomater. 2014, 10, 2894-2906.

(59) Tzoneva, R.; Faucheux, N.; Groth, T. Biochim. Biophys. Acta BBA - Gen. Subj. 2007, 1770, 1538-1547.

(60) Truong, V. K.; Lapovok, R.; Estrin, Y. S.; Rundell, S.; Wang, J. Y.; Fluke, C. J.; Crawford, R. J.; Ivanova, E. P. Biomaterials 2010, 31, 3674-3683.

(61) Mitik-Dineva, N.; Wang, J.; Truong, V. K.; Stoddart, P.; Malherbe, F.; Crawford, R. J.; Ivanova, E. P. Curr. Microbiol. 2009, 58, 268-273.

(62) Truong, V. K.; Rundell, S.; Lapovok, R.; Estrin, Y.; Wang, J. Y.; Berndt, C. C.; Barnes, D. G.; Fluke, C. J.; Crawford, R. J.; Ivanova, E. P. Appl. Microbiol. Biotechnol. 2009, 83, 925-937.

(63) Kunzler, T. P.; Drobek, T.; Schuler, M.; Spencer, N. D. Biomaterials 2007, 28, 2175-2182.

(64) Könönen, M.; Hormia, M.; Kivilahti, J.; Hautaniemi, J.; Thesleff, I. J. Biomed. Mater. Res. 1992, 26, 13251341.

(65) Ponsonnet, L.; Comte, V.; Othmane, A.; Lagneau, C.; Charbonnier, M.; Lissac, M.; Jaffrezic, N. Mater. Sci. Eng. C 2002, 21, 157-165.

(66) Wirth, C.; Comte, V.; Lagneau, C.; Exbrayat, P.; Lissac, M.; Jaffrezic-Renault, N.; Ponsonnet, L. Mater. Sci. Eng. C 2005, 25, 51-60.

(67) Mas-Moruno, C.; Fraioli, R.; Albericio, F.; Manero, J. M.; Gil, F. J. ACS Appl. Mater. Interfaces 2014, 6, 6525-6536.

(68) Yoo, S. Y.; Park, S. J.; Jeong, D. K.; Kim, K.-W.; Lim, S.-H.; Lee, S.-H.; Choe, S.-J.; Chang, Y.-H.; Park, I.; Kook, J.-K. J. Microbiol. Seoul Korea 2007, 45, 246-255.

(69) Pham, L. C.; van Spanning, R. J. M.; Röling, W. F. M.; Prosperi, A. C.; Terefework, Z.; Ten Cate, J. M.; Crielaard, W.; Zaura, E. Arch. Oral Biol. 2009, 54, 132-137.

(70) Godoy-Gallardo, M.; Rodríguez-Hernández, A. G.; Delgado, L. M.; Manero, J. M.; Javier Gil, F.; Rodríguez, D. Clin. Oral Implants Res. 2014, n/a - n/a. 


\section{CORRESPONDING AUTHOR}

*Daniel Rodriguez Rius; ETSEIB-UPC - Department of Materials Science and Metallurgical Engineering; Av. Diagonal 647, 08028 - Barcelona, Spain; Phone: +34 934010711; Fax: +34 934016706; daniel.rodriguez.rius@upc.edu 


\section{TABLE OF CONTENTS GRAPHIC}

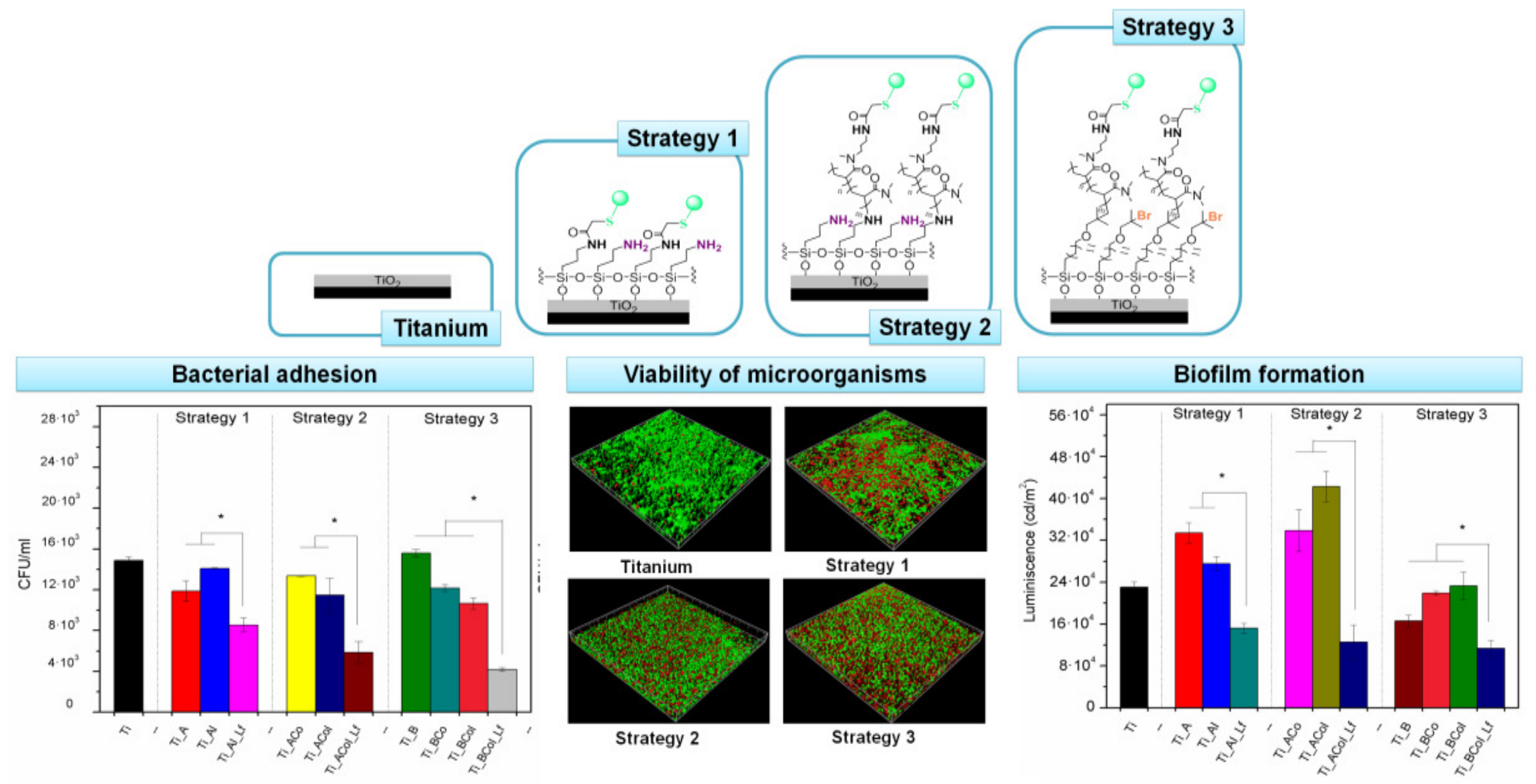

